José Roda Peña

Sevilla, Universidad de Sevilla

\title{
La escultura española en tiempos de El Greco
}

"Por hermosa que sea, la pintura es menos eterna que la escultura".

(Leone Leoni)

$\mathrm{Al}$ confrontar las imágenes de San Jerónimo penitente que tallaran Juan de Anchieta con destino al retablo de la capilla Zaporta en la seo de Zaragoza y Juan Martínez Montañés para el altar mayor de la iglesia del monasterio de San Isidoro del Campo en Santiponce (Sevilla), advertimos con claridad el recorrido trazado por la escultura española en tiempos de El Greco (Candía, Creta, 1541-Toledo, 1614), desde el manierismo romanista impregnado de la influencia de Miguel Ángel, hasta el primer naturalismo barroco que va imponiéndose con paso firme a medida que avanza el siglo XVII ${ }^{1}$.

En el panorama de la escultura renacentista y manierista española, los planteamientos estéticos más renovadores, casi siempre inspirados en el modelo italiano, conviven con otras opciones estilísticas, técnicas y expresivas que pudieran calificarse de tradicionales, aunque por lo general pasadas en sus componentes formales por el tamiz de la "modernidad". Fuera del ámbito cortesano, donde pudo desarrollarse con mayor amplitud la escultura profana, hubo escultores de gran talento, ya durante las últimas décadas del siglo XVI, que supieron aplicar a la predominante imaginería religiosa y devocional las composiciones y criterios figurativos propios del clasicismo, aunque reinterpretados en clave emocional y dramática por el espíritu contrarreformista, tan atento a los intereses

DOI: http://dx.doi.org/10.15633/9788374385114.08

1 Para el estudio de la escultura española de la segunda mitad del siglo XVI y primeros lustros del XVII siguen resultando del máximo interés las monografías de: J. M. Azcárate, Escultura del siglo XVI, Madrid 1958 (Ars Hispaniae. Historia Universal del Arte Hispánico, XIII), passim; J. Camón Aznar, La escultura y la rejería españolas del siglo XVI, Madrid 1961 (Summa Artis. Historia General del Arte, XVIII), passim; F. Checa, Pintura y escultura del Renacimiento en España, 1450-1600, Madrid 1983, passim; J. J. Vélez Chaurri, Becerra, Anchieta y la escultura romanista, Madrid 1992, passim. 
de la piedad popular, que defendía el decreto tridentino sobre las imágenes sagradas, y su ulterior aplicación por parte de los diferentes sínodos provinciales. En función de la cualificación y de los intereses culturales y artísticos de los comitentes, así como de la diversidad de las zonas geográficas y ciudades integradas en el territorio peninsular, nos encontraremos con una sugestiva variedad de géneros escultóricos, a los que intentaremos aproximarnos someramente.

\section{La escultura cortesana}

Los escultores al servicio del rey definen un arte oficial que traduce la imagen de la monarquía hispánica, utilizando materiales nobles como el bronce y el mármol. Si durante el reinado de Carlos V (1500-1558) se asistió a un proceso de paulatina decantación clasicista en el arte español, puede afirmarse que su culminación se alcanzaría bajo el gobierno de Felipe II (1527-1598), adoptándose como lenguaje oficial de la monarquía ${ }^{2}$. Los escultores cortesanos más importantes del siglo XVI fueron los italianos Leone y Pompeo Leoni, padre e hijo, naturales de Arezzo y vecinos de Milán, quienes destacarían por su virtuosismo técnico y un alto grado de corrección formal.

A Leone Leoni (1509-1590) lo encontramos trabajando al servicio del emperador Carlos desde 1546, acaparando desde mediados de la década de 1550 casi todos los encargos reales, cuya realización afronta en su obrador milanés con la activa colaboración de su hijo Pompeo (c. 1533-1608), quien terminaría por residir más de cincuenta años en la corte española ${ }^{3}$. Ocupa un lugar principal el grupo alegórico de Carlos V y el Furor (1551-1564) del Museo Nacional del Prado (il. 84), donde la mayestática y grave presencia del emperador - cuya armadura se puede desmontar, ofreciéndosenos su figura desnuda, como la de un héroe griego - se yergue dominadora sobre el encolerizado Furor que se retuerce a sus pies, aludiéndose así al conjunto de sus victorias y de su talante pacificador ${ }^{4}$.

Resulta bien conocida la comparación que fray José de Sigüenza estableció entre el monasterio de San Lorenzo de El Escorial con el tabernáculo de Moisés y el templo de Salomón. Es verdad que, desde un punto de vista meramente cuantitativo, la escultura escasea en los

2 M. A. Castillo, El Renacimiento y el Manierismo en España, Madrid 1999, p. 94; A. M. Arias de Cossío, El Arte del Renacimiento español, Madrid 2009, p. 307.

3 Una biografía de ambos escultores en relación con la corte de España nos la ofrece M. Estella, Los Leoni, escultores entre Italia y España, [en:] Los Leoni (1509-1608). Escultores del Renacimiento italiano al servicio de la corte de España, ed. J. Urrea Fernández, cat. exp., Madrid, Museo Nacional del Prado, Madrid 1994, p. 29-62.

4 R. Coppel Areizaga, Carlos V y el Furor, [en:] Los Leoni (1509-1608), op. cit., p. 102-109. 


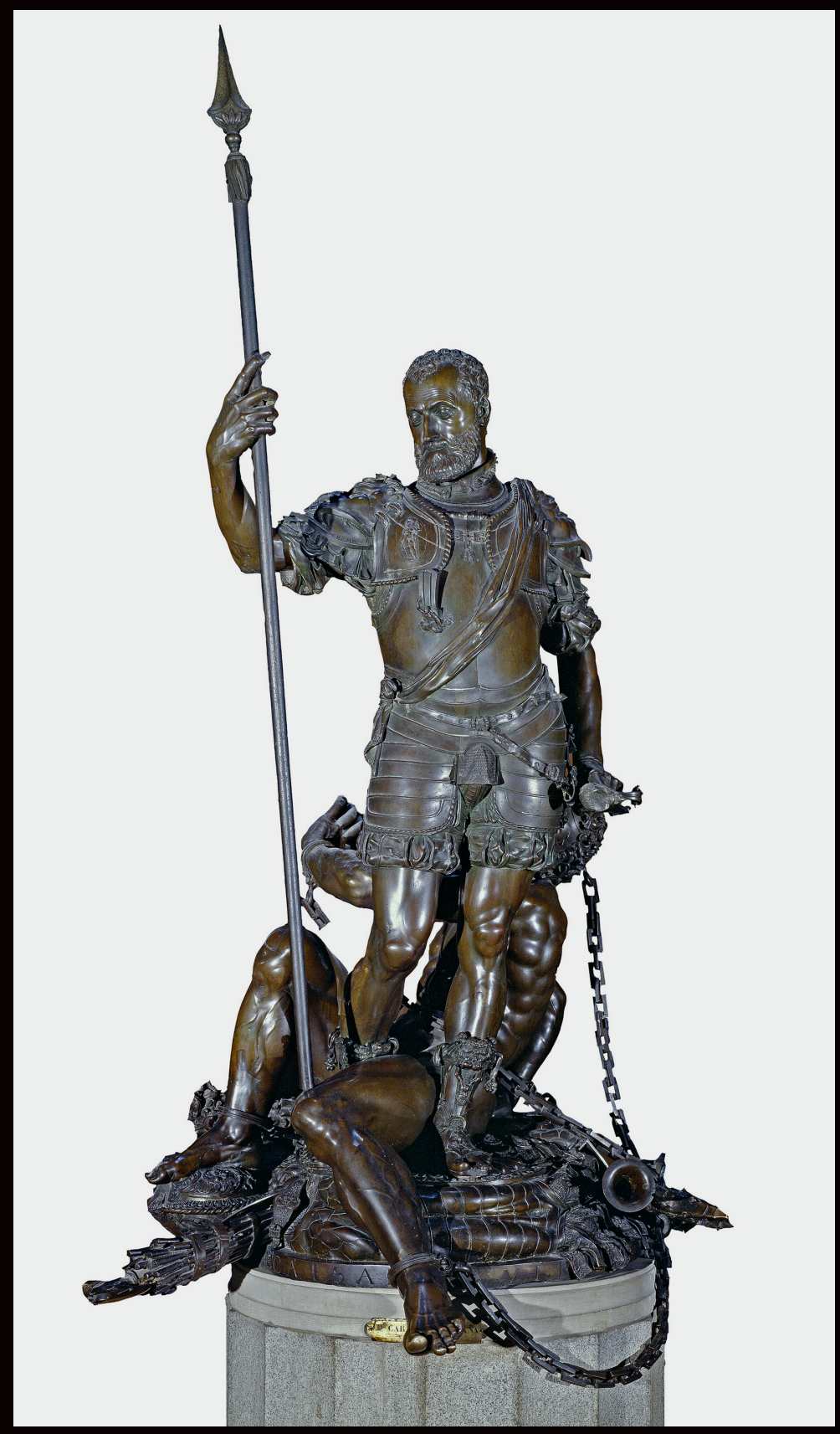

84. Leone y Pompeo Leoni, Carlos V y el Furor, 1564, Madrid, Museo Nacional del Prado 


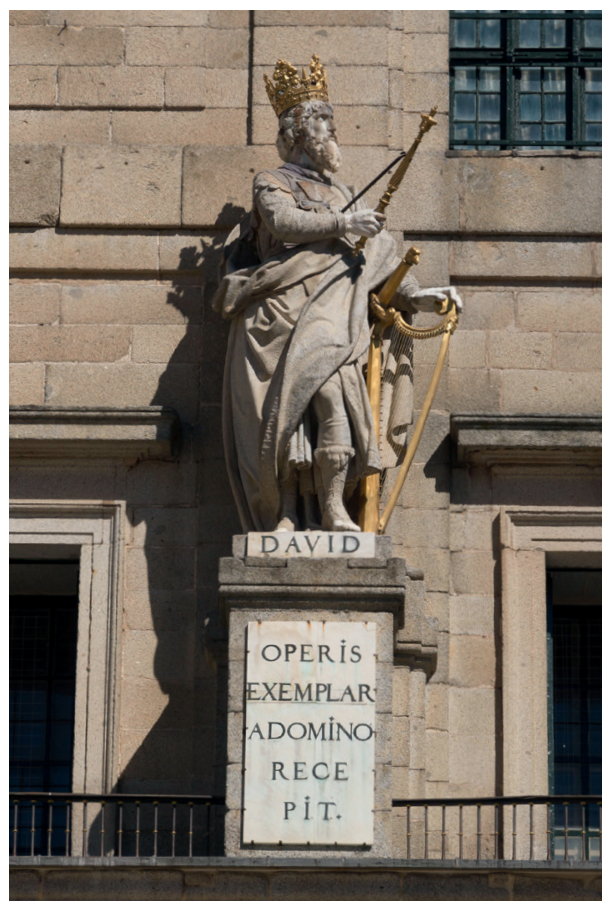

85. Juan Bautista Monegro, Rey David, 15811584, El Escorial, fachada principal de la basílica de San Lorenzo programas escurialenses ${ }^{5}$, pero no es menos cierto que los lugares más relevantes de su recorrido quedan cualificados por la presencia de los bultos monumentales de Juan Bautista Monegro (c. 1545-1621) ${ }^{6}$ y de los Leoni. Así, en la fachada exterior, es la estatua de San Lorenzo (1582-1583), tallada por Monegro en granito y mármol, la que nos indica la identidad del santo a quien se dedica el edificio, del mismo modo que las armas del monarca delatan al impulsor de su construcción. El mencionado simbolismo hierosimilitano queda perfectamente explicitado en las efigies pétreas de los reyes de Judá (David, Salomón, Ezequías, Josías, Josafat y Manasés) que campean en la fachada principal de la basílica, esculpidas por Monegro entre 1581 y 1584 (il. 85). Asimismo, el sentido de panteón dinástico con que se quiso dotar al conjunto, se refleja, a ambos lados de la capilla mayor del templo, en los soberbios grupos funerarios de Pompeo Leoni de las familias de Carlos V (1592-1598) y Felipe II (1597-1600) (il. 86), cuyos componentes se han representado con singular empaque y dignidad, reverentemente genuflexos en perpetua adoración al Santísimo Sacramento reservado o expuesto en el tabernáculo del grandioso retablo mayor de jaspes polícromos. Tal dispositivo arquitectónico responde a un diseño de Juan de Herrera - materializado por Jacopo da Trezzo

5 F. Checa Cremades, Un príncipe del Renacimiento. El valor de las imágenes en la corte de Felipe II, [en:] Felipe II. Un monarca y su época. Un príncipe del Renacimiento, ed. F. Checa Cremades, cat. exp., Madrid, Museo Nacional del Prado, Madrid 1998, p. 49-50.

6 Escultor y arquitecto, se duda sobre si su nacimiento aconteció en la montaña santanderina o en la ciudad de Toledo, su lugar habitual de residencia. Su primer encargo conocido lo forman las figuras de la Fe y la Caridad para la puerta de la Presentación de la catedral toledana, contratadas en 1569. Para 1577 se encontraba trabajando en los retablos y custodia del monasterio de Santo Domingo el Antiguo, de Toledo, donde debía seguir las trazas suministradas por El Greco, en las que sin embargo introdujo ciertas modificaciones, con el consiguiente disgusto del cretense. A. de Vicente y García, La escultura de Juan Bautista Monegro en el Real Monasterio de San Lorenzo de El Escorial, Madrid 1990, passim. 


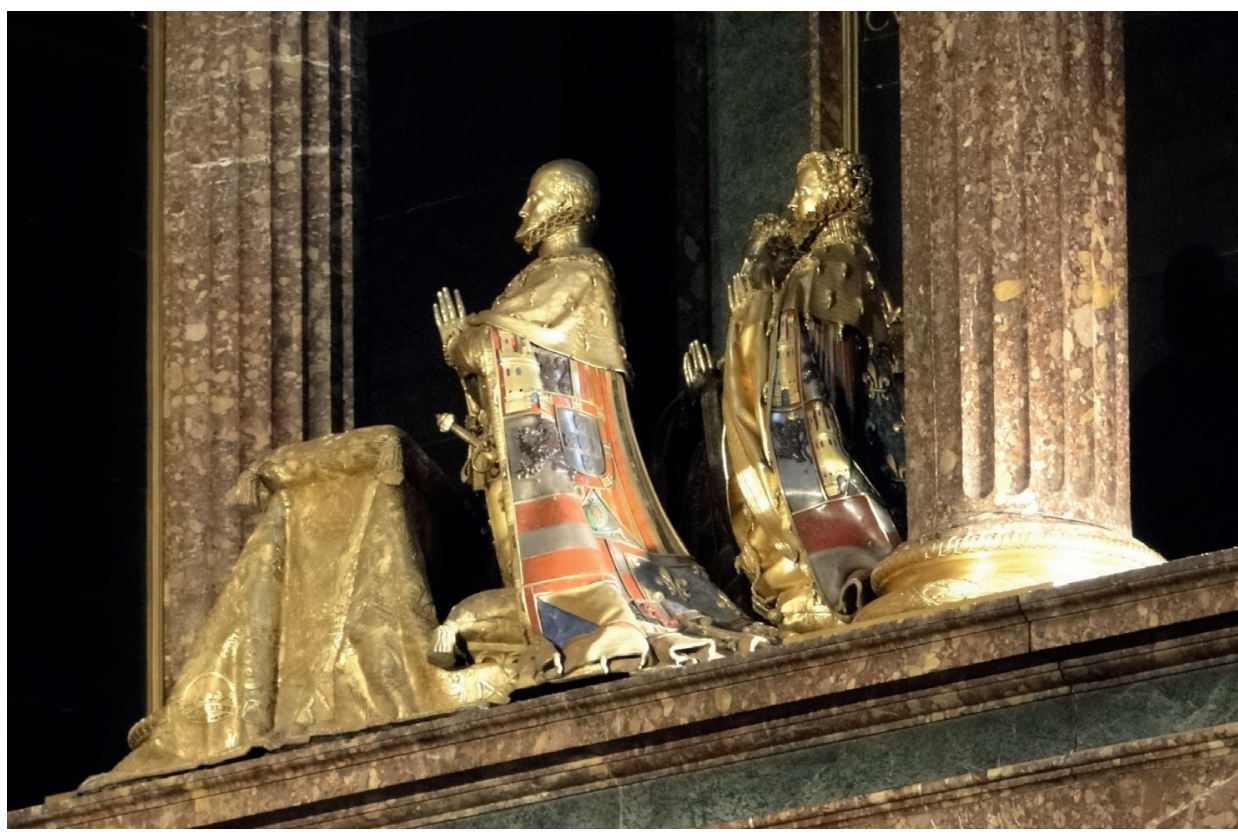

86. Pompeo Leoni, Cenotafio de Felipe II y su familia, 1597-1600, El Escorial, basílica de San Lorenzo

y Juan Bautista Comane - en el más severo de los lenguajes clásicos, alojándose en sus tres cuerpos y ático quince esculturas en bronce dorado de Leone y Pompeo Leoni (con la participación en algunas de ellas del flamenco Adriaen de Vries): los padres de la Iglesia latina, los evangelistas, los apóstoles Santiago, Andrés, Pedro y Pablo, y el Calvario (1579-1589), junto a pinturas de Federico Zuccari y Peregrino Tibaldi, desarrollándose una suerte de ciclo redentorista a través del Nacimiento, Pasión, Muerte y Resurrección de Cristo, en unión de las escenas de Pentecostés y de la Asunción de María con que se culmina este camino de salvación ${ }^{7}$. A Monegro también correspondió a partir de 1589 la ejecución de los cuatro evangelistas de mármol situados en las hornacinas del templete ochavado que centra el patio al que dan nombre, cada uno de los cuales se acompaña, en imágenes

7 R. Mulcahy, The Decoration of the Royal Basilica of El Escorial, Cambridge 1994, especialmente los capítulos sobre el retablo mayor (pp. 137-188) y los monumentos funerarios de los Leoni (pp. 189-211); eadem, El arte religioso y su función en la corte de Felipe II, [en:] Felipe II. Un monarca y su época..., op. cit., p. 166: "Los grupos funerarios de bronce dorado de Pompeo Leoni representan a los Habsburgos españoles en perpetua adoración de la Eucaristía, rindiendo homenaje a Dios de quien procede su poder y su derecho a reinar. Las efigies son representaciones públicas de los cadáveres regios depositados en el panteón bajo el altar mayor. No elevan sus plegarias solo por su propia salvación, sino también por la de la dinastía". 


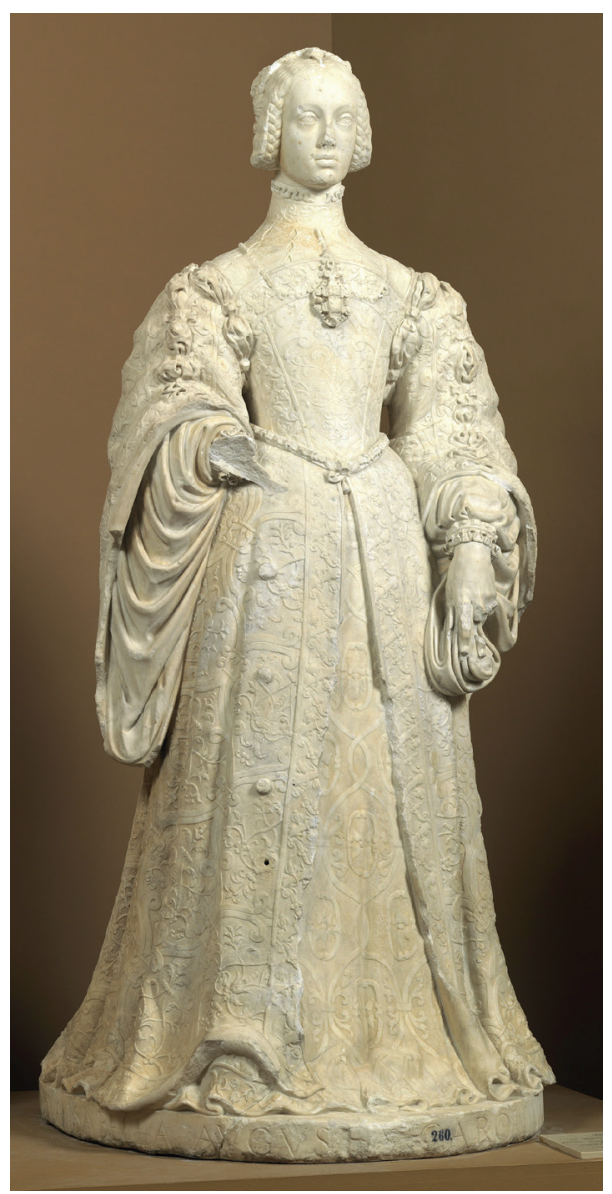

87. Pompeo Leoni, La emperatriz Isabel de Portugal, 1572, Madrid, Museo Nacional del Prado individualizadas, de su particular símbolo del tetramorfos: ángel, león, toro y águila.

El retrato de corte se revela como una de las manifestaciones de mayor interés durante este período, siendo los Leoni sus cultivadores más significativos en bajorrelieves, medallas, bustos y estatuas de cuerpo entero, tanto en mármol como en bronce. Díganlo si no los retratos exentos que se conservan en el Museo Nacional del Prado de Carlos V (c. 1553-1554), la emperatriz Isabel de Portugal (1550-1555 y 1572, firmado este último en solitario por Pompeo) (il. 87), la reina María de Hungría (15531555 y 1553-1564) y Felipe II (1551-1553), donde la distancia, la frialdad expresiva y la solemnidad se revelan como sus notas más características, amén de su envaramiento corporal y minucioso detallismo en la talla de corazas y de los adornos indumentarios. También resulta de una sugestiva belleza la estatua orante que Pompeo contratara en 1574 para la tumba de doña Juana de Austria en el monasterio de las Descalzas Reales de Madrid, que ella misma fundara. Como cabría esperar, los nobles y otros personajes de gran relevancia política, eclesiástica y cultural, pertenecientes a los ámbitos humanistas más sofisticados, desearon emular el retrato áulico, tanto pictórico como escultórico, acudiendo a los artistas de mayor renombre que habían laborado en El Escorial, de manera que pueden traerse una vez más a colación los nombres de Juan Bautista Monegro, a propósito del busto que algunos le atribuyen del ingeniero Juanelo Turriano (c. 1587), en el Museo de Santa Cruz de Toledo, y de Pompeo Leoni con sus esculturas para el mausoleo del inquisidor Fernando de Valdés en la antigua colegiata asturiana de Santa María la Mayor de Salas (1576), cuyo retrato está realizado ya en clave naturalista; dedicación compartida por el eminente platero y escultor Juan de Arfe y Villafañe (1535-1603) en sus estatuas sepulcrales de los duques de Lerma para el convento de 
San Pablo de Valladolid - sobre modelos suministrados en 1601 por Pompeo Leoni - y la del arzobispo Cristóbal de Rojas y Sandoval en la colegiata de San Pedro de Lerma. El hieratismo y compostura de las efigies anteriores contrasta con el aire más libre y desenvuelto que muestra el inquisidor apostólico y canónigo de la catedral de Sevilla Antonio del Corro, docto clérigo a quien encontramos reclinado y acodado, leyendo ensimismadamente en el sepulcro marmóreo que le tallara Juan Bautista Vázquez el Viejo en 1564, con diseño de Hernán Ruiz el Joven, para la parroquia de Santa María de los Ángeles en San Vicente de la Barquera (Santander), donde se encontraba el panteón familiar ${ }^{8}$.

\section{Los retablos escultóricos}

La imagen sagrada se pone al servicio de la ortodoxia católica y el retablo se convertirá en la cátedra desde la que se impartan sus principales lecciones dogmáticas e iconográficas, reforzadas por la retórica cristiana desplegada en los sermones predicados desde los vecinos púlpitos. Ambos discursos, el visual y el acústico, a fin de prender la atención del fiel, y no distraerlo con argumentos superfluos y gesticulaciones extremas, debían regirse por un sentido del orden y de la legibilidad compositiva, claramente expresados en la articulación formal de estos dispositivos arquitectónicos clasicistas o puristas, que sin embargo no podían estar reñidos con su catártica capacidad para emocionar e impresionar vivamente los sentidos.

La traza de los retablos, muy influenciada por la tratadística italiana - en especial Serlio, Vignola y Palladio - se ordena racionalmente por medio de la superposición de varios cuerpos, divididos en calles y entrecalles que componen un conjunto proporcionado de líneas verticales y horizontales. Predomina el carácter tectónico, la ortodoxia vitruviana y la claridad estructural que imponen los órdenes clásicos sobre el magma decorativo que antes poblaba el retablo plateresco. El ornato a base de grutescos, por el carácter pagano que ahora se le adjudica, se verá sustituido por rameados, cartelas, guirnaldas vegetales y frutales, angelitos e ignudi y gran diversidad de motivos geométricos.

Indudablemente, el retablo mayor de la catedral de Astorga (il. 88), concertado en 1558 por el pintor y escultor Gaspar Becerra - que había llegado el año anterior a Valladolid después de doce años pasados en Roma, colaborando con Giorgio Vasari y Daniele da Volterra - supone el punto de partida de esta nueva concepción del retablo

8 El estudio más penetrante y completo de este sepulcro se debe a E. Gómez Piñol, Las atribuciones en el estudio de la escultura: nuevas propuestas y reflexiones sobre obras de la escuela sevillana de los siglos XVI y XVII, [en:] Nuevas perspectivas críticas sobre historia de la escultura sevillana, ed. C. Bellvís Zambrano, Sevilla 2007, p. 28-34. 


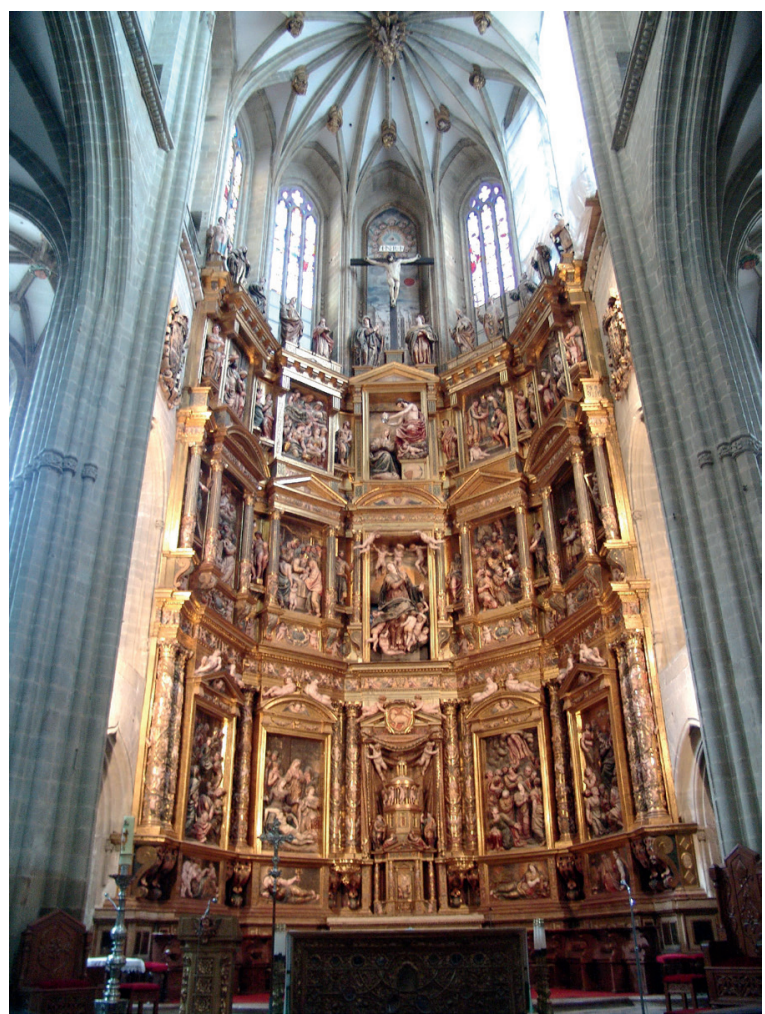

88. Gaspar Becerra, retablo mayor, 1558-1563, Astorga (León), catedral español por tierras de Castilla la Vieja, dado el carácter absolutamente innovador de su diseño, ornamentación y programa iconográfico, contando para su plasmación con un importante plantel de colaboradores $^{9}$. En estos momentos iniciales del romanismo miguelangelesco impresiona por su colosal envergadura y la excelsa calidad de su estatuaria el retablo mayor del monasterio de Santa Clara de Briviesca (Burgos), cuyo proceso constructivo, ciertamente largo y complejo, comenzó en 1551 por mano del burgalés Diego Guillén, aunque a partir de 1566 se hizo cargo del mismo Pedro López de Gámiz - a quien en verdad habría que adjudicar su traza imaginero de Miranda de Ebro, quien se auxilió de un nutrido equipo que concluyó el trabajo en 1570, adjudicándose acertadamente a Juan de Anchieta la mayor parte del imponente repertorio de imágenes de contenido eminentemente mariano, acompañado por un apostolado y otros santos ${ }^{10}$. La pericia de López de Gámiz como tracista de retablos se manifestó, por segunda vez en Briviesca, en el retablo

9 M. C. García Gaínza, El retablo de Astorga. Una nueva tipología de retablo de época de Felipe II, [en:] Felipe II y las artes. Actas del Congreso Internacional 9-12 de diciembre 1998, Madrid 2000, p. 623-631; M. Arias et al., El retablo mayor de la catedral de Astorga: historia y restauración, Salamanca 2001, passim.

10 S. Andrés Ordax, El foco de escultura romanista de Miranda de Ebro: Pedro López de Gámiz y Diego Marquina, Valladolid 1984, passim; A. A. Barrón García, El retablo de Santa Clara de Briviesca en el romanismo norteño, "Boletín del Museo e Instituto Camón Aznar" 1999, no. 78-79, p. 241-300; L. Vasallo Toranzo, Gámiz, Anchieta y Juni: el pleito por el retablo de Briviesca, "Archivo Español de Arte” 2009, no. 328, p. 355-366. 
de Santa Casilda de la colegiata de Santa María la Mayor, cuyo mentor fue el obispo de Segorbe don Juan de Muñatones, con relieves e imaginería exenta debidos indudablemente a Juan de Anchieta ${ }^{11}$.

En Valladolid, crisol de tendencias y centro artístico de máxima importancia a pesar de la designación de Madrid como capital en 1561, fue muy profunda la huella que en este capítulo de la ensambladura de retablos dejara el escultor originario del norte de Francia Juan de Juni (1506-1577) ${ }^{12}$. El que contratara para la iglesia de Santa María la Antigua en 1545, cuya finalización se dilató hasta 1562, es una de sus realizaciones más emblemáticas, ofreciendo una gran originalidad en su planteamiento arquitectónico, donde la escultura queda magistralmente integrada, mostrando una perspectiva convergente en las escenas en relieve, al tiempo que las figuras de bulto se debaten por librarse de la angostura que ofrecen los intercolumnios. Prueba evidente de que en Valladolid también se impuso la maniera romana es que al concertar Juan de Juni en 1573 el retablo mayor de la parroquia de Santa María de Mediavilla en Medina de Rioseco, tuvo que atenerse a la traza que había suministrado con anterioridad Gaspar Becerra; el fallecimiento del maestro francés en 1577 - justamente el año en que El Greco llegara a España estableciéndose en Toledo determinó que su terminación recayera en manos de su discípulo dilecto, el escultor leonés afincado en Valladolid Esteban Jordán (c. 1530-1598) ${ }^{13}$, quien logró culminarlo en 1590. Este último supo fundir las influencias de Juni, Berruguete y Becerra, con el que había trabajado en Astorga, siendo su principal obra en la capital del Pisuerga el retablo mayor de la iglesia de la Magdalena (1571), aunque sus aportaciones más consumadas ya en la última década del siglo XVI, fuesen los retablos mayores de la parroquia de Santa María en Alaejos y del monasterio catalán de Nuestra Señora de Montserrat, diseñado este último por Francisco de Mora y destruido en la invasión francesa ${ }^{14}$.

El escultor vasco Juan de Anchieta (c. 1533-1588) se revela como una de las más poderosas personalidades de la escultura española del último tercio del siglo $\mathrm{XVI}^{15}$. Formado artísticamente en el importante foco escultórico de Valladolid, se relacionó con Inocencio

11 J. J. Vélez Chaurri, P. L. Echeverría Goñi, Contrarreforma y Manierismo en Briviesca. Don Juan de Muñatones y el retablo de Santa Casilda, [en:] El Mediterráneo y el Arte Español, eds. J. Bérchez, M. Gómez Ferrer, A. Serra, Valencia 1998, p. 130-133.

12 J. J. Martín González, Juan de Juni. Vida y obra, Madrid 1974, passim; M. A. Fernández del Hoyo, Juan de Juni, escultor, Valladolid 2012, passim.

13 J. J. Martín González, Esteban Jordán, Valladolid 1952, passim.

14 F. Marías Franco, Esteban Jordán, Francisco de Mora y el retablo mayor de Montserrat, "Boletín del Seminario de Estudios de Arte y Arqueología" 1982, no. 48, p. 383-388.

15 De fundamental lectura resulta la monografía que le dedicara M. C. García Gaínza: Juan de Anchieta, escultor del Renacimiento, Madrid 2008, passim. 


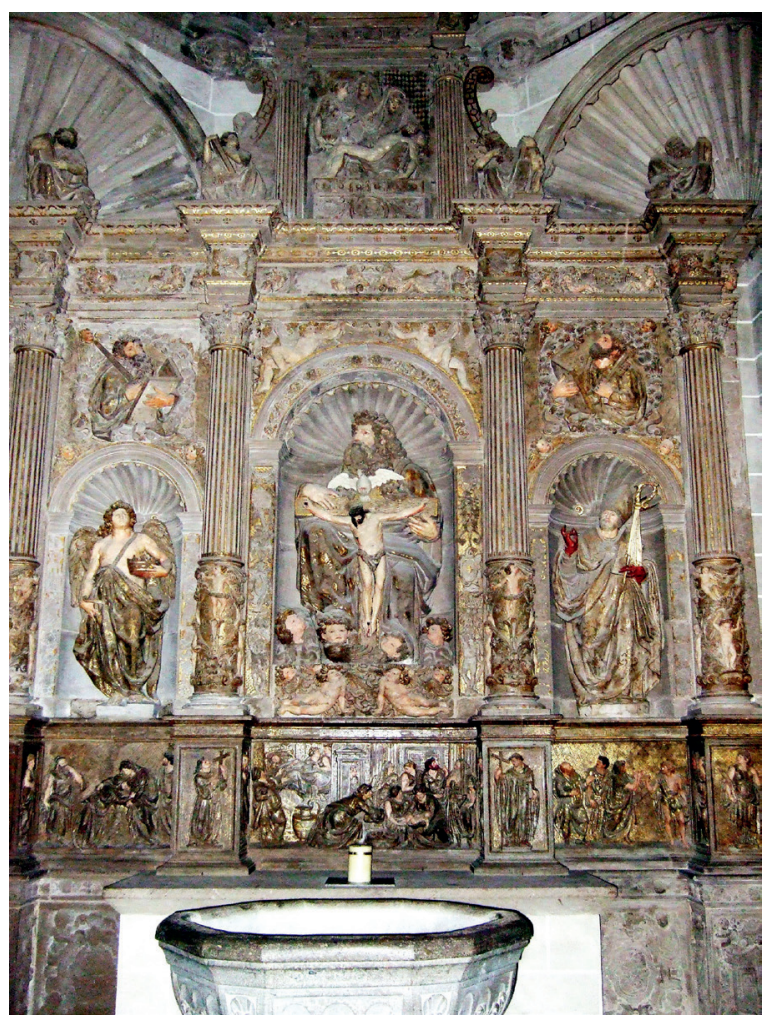

89. Juan de Anchieta, retablo de la Trinidad, 1572-1578, Jaca (Huesca), catedral
Berruguete, Pedro López de Gámiz, Esteban Jordán y Juan de Juni, quien sintió un especial aprecio y admiración por él. Tras marcharse de Valladolid en 1570, trabajó en Burgos, Aragón, el País Vasco, La Rioja $y$, especialmente, en Navarra, por lo que su influencia fue muy extensa. Actividad incesante que se concreta, además de lo comentado en Briviesca, en retablos tan destacados como el de los arcángeles de la capilla Zaporta en la catedral de Zaragoza, el de la Trinidad de la seo de Jaca - cuyo Padre Eterno constituye una de las más felices réplicas del Moisés de Miguel Ángel (il. 89), el de San Pedro de Zumaya (Guipúzcoa) y, en tierras navarras, los mayores de las iglesias parroquiales de Cáseda, Añorbe,

Aoiz - muy modificado y repintado en el siglo XVIII - y Tafalla, concertado el mismo año de su óbito, en 1588, de manera que la mayor parte de su mazonería y esculturas se deben a su discípulo Pedro González de San Pedro, quien se atuvo fielmente al diseño suministrado por su maestro.

Que la mayor parte de los escultores activos en Sevilla durante el último tercio del siglo XVI fueron, al mismo tiempo, entalladores de retablos, es un hecho probado desde el punto de vista documental ${ }^{16}$. Es el caso del salmantino Juan Bautista Vázquez el

16 J. M. Palomero Páramo, El retablo sevillano del Renacimiento. Análisis y evolución (1560-1629), Sevilla 1983, passim; F. J. Herrera García, El retablo sevillano en el tránsito de los siglos XVI al XVII: tracistas, modelos, tratados, [en:] La escultura del primer naturalismo en Andalucía e Hispanoamérica (1580-1625), ed. L. Gila Medina, Madrid 2010, p. 307-330. 
Viejo (c. 1525-1588) ${ }^{17}$, llegado a la ciudad de la Giralda para continuar con la talla de los relieves del retablo mayor de la cartuja de Santa María de las Cuevas, labor iniciada por el abulense Isidro de Villoldo en 1553 que se había visto interrumpida por su repentino fallecimiento en $1558^{18}$. En 1562 se comprometió a esculpir las historias de la creación de Adán y Eva y la expulsión del Paraíso para el banco del retablo mayor de la catedral sevillana, las cuales, bajo la influencia miguelangelesca de esas mismas escenas pintadas en la bóveda de la Capilla Sixtina, vienen a ilustrar la decidida orientación clasicista que asume la escultura sevillana a partir de entonces. Intervino en algunas de las ensambladuras más re-

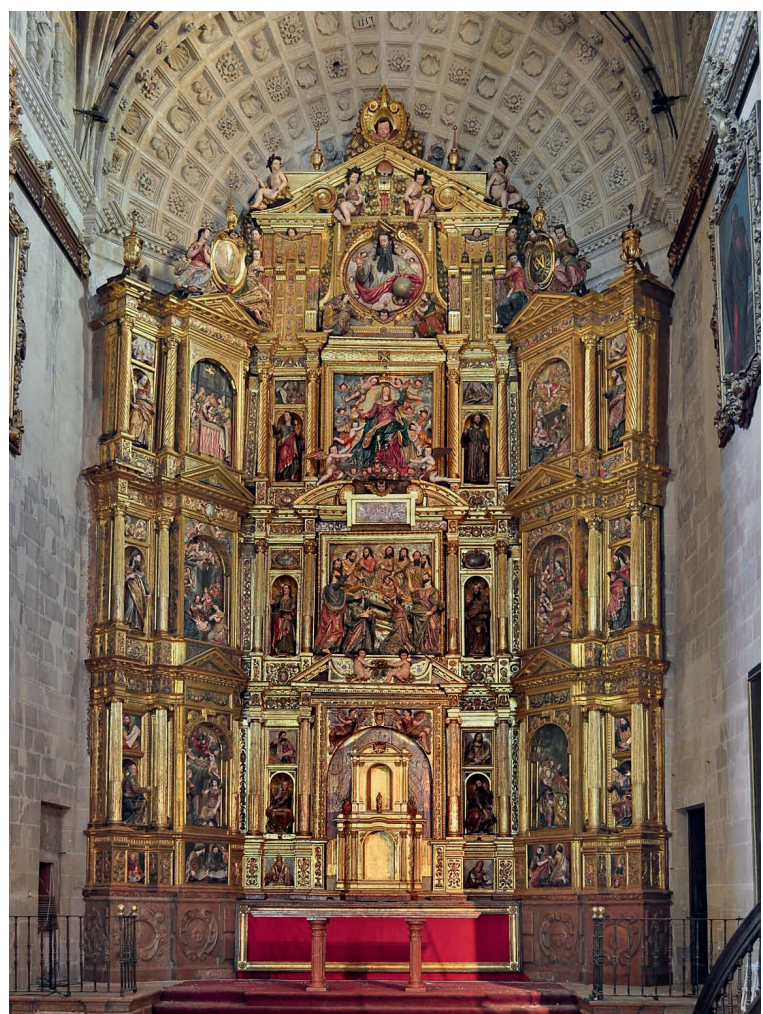

90. Jerónimo Hernández, Juan Bautista Vázquez el Mozo, Andrés de Ocampo et al., retablo mayor, a partir de 1585, Arcos de la Frontera (Cádiz), iglesia de Santa María levantes que por entonces se alzaron en la archidiócesis hispalense, caso de los retablos mayores de Santa María de Carmona (Sevilla) y Santa María de Medina Sidonia (Cádiz), encomendándosele también en 1572 la imaginería del retablo mayor de San Mateo de Lucena (Córdoba), cuya traza, que incorpora cuatro columnas jónicas de orden gigante, se debe a su discípulo el abulense Jerónimo Hernández $(1540-1586)^{19}$. Este último es otro de los forjadores de la que ha venido en calificarse como escuela sevillana de escultura, al tiempo que fue un

17 M. Estella Marcos, Juan Bautista Vázquez el Viejo en Castilla y América, Nicolás de Vergara, su colaborador, Madrid 1990, passim.

18 J. M. Parrado del Olmo, Los escultores seguidores de Berruguete en Ávila, Ávila 1981, p. 200, $462-463$.

19 J. M. Palomero Páramo, Gerónimo Hernández, Sevilla 1982, passim. 
consumado tracista de retablos, actividad en la que de seguro recibiría sabias lecciones de su suegro el gran arquitecto Hernán Ruiz el Joven. En el retablo mayor de la parroquia de Santa María de Arcos de la Frontera (Cádiz), aunque fueron Jerónimo Hernández y Juan Bautista Vázquez el Mozo quienes asumieron en 1585 el ensamblaje y escultura del mismo siguiendo el diseño suministrado por el maestro mayor catedralicio Pedro Díaz de Palacios, lo cierto es que durante las sucesivas etapas por las que atravesó esta formidable máquina lignaria se dieron cita allí algunos de los principales escultores de esta generación que trabajó en el entorno del antiguo reino de Sevilla, como Andrés de Ocampo, Gaspar del Águila, Blas Hernández Bello, Miguel Adán y Diego López Bueno (il. 90). Adentrándose en el siglo XVII, la obra de Juan Martínez Montañés $(1568-1649)^{20}$ supone la culminación del retablo romanista en el ámbito de influencia sevillano; entre sus principales logros cabe destacar el retablo mayor de San Isidoro del Campo, que le fue encargado por su comunidad conventual en 1609, yendo parejas sus logradas proporciones y la calidad de sus esculturas.

Por su parte, en Andalucía oriental, la obra que vino a marcar el cambio estilístico en los retablos granadinos, fue el mayor del monasterio de San Jerónimo (il. 91), cuya estructura es la más amplia y monumental de cuantas se emprendieron durante el siglo XVI en la ciudad del Darro. Tras contratarse su realización en 1576, Lázaro de Velasco aportó unas nuevas trazas en 1579, registrándose en 1603 una ampliación diseñada por Pedro de Orea. La escultura correspondiente al proyecto inicial se viene atribuyendo al sevillano Juan Bautista Vázquez el Mozo y a Melchor de Turín, mientras que para la zona aumentada se han barajado los nombres de Pablo de Rojas, Bernabé de Gaviria y Diego de Aranda, interviniendo como policromadores Juan de Aragón, en la primera parte, y Pedro de Raxis, en la segunda. Muy valiosas fueron las aportaciones retablísticas de Ambrosio de Vico y Gaspar Guerrero ${ }^{21}$.

\section{Las imágenes de devoción}

La escultura religiosa española de la segunda mitad del siglo XVI y primeros años del Seiscientos se adapta a las necesidades del arte de la Contrarreforma y responde a los

20 B. Gilman Proske, Juan Martínez Montañés: sevillian sculptor, New York 1967, passim; J. Hernández Díaz, Juan Martínez Montañés. El Lisipo andaluz (1568-1649), Sevilla 1976, passim; idem, Juan Martínez Montañés (1568-1649), Sevilla 1987, passim; Juan Martínez Montañés, ed. E. Pareja López, Sevilla 2008, passim; J. L. Romero Torres, Juan Martínez Montañés, maestro de generaciones, [en:] J. L. Romero Torres, P. Jaime Moreno de Soto, Martínez Montañés y Osuna a comienzos del Barroco, Osuna 2011, p. 131-171.

21 J. M. Gómez-Moreno Calera, Evolución de la retablística granadina entre los siglos XVI y XVII, [en:] La escultura del primer naturalismo en Andalucía e Hispanoamérica..., op. cit., p. 239-272. 
preceptos dimanados de Trento, que no ofrecieron indicaciones de estilo, pero que en su célebre sesión XXV (3 de diciembre de 1563) sí fijaron determinados aspectos que incidieron en su carácter catequético y en su finalidad didáctica y moral. En las ulteriores constituciones sinodales, los obispos señalan las causas que podían provocar entre los fieles una falta de devoción hacia las imágenes sagradas, poniendo en peligro su auténtico sentido adoctrinador. Cargan, así, contra la profanidad de algunas indumentarias con que dichas efigies eran revestidas, velan por la debida honestidad, propiedad y decoro de sus formas y contenidos, y tratan de ejercer un mayor control sobre algunos aspectos referidos a su iconografía, potenciando además determinados temas y verdades de

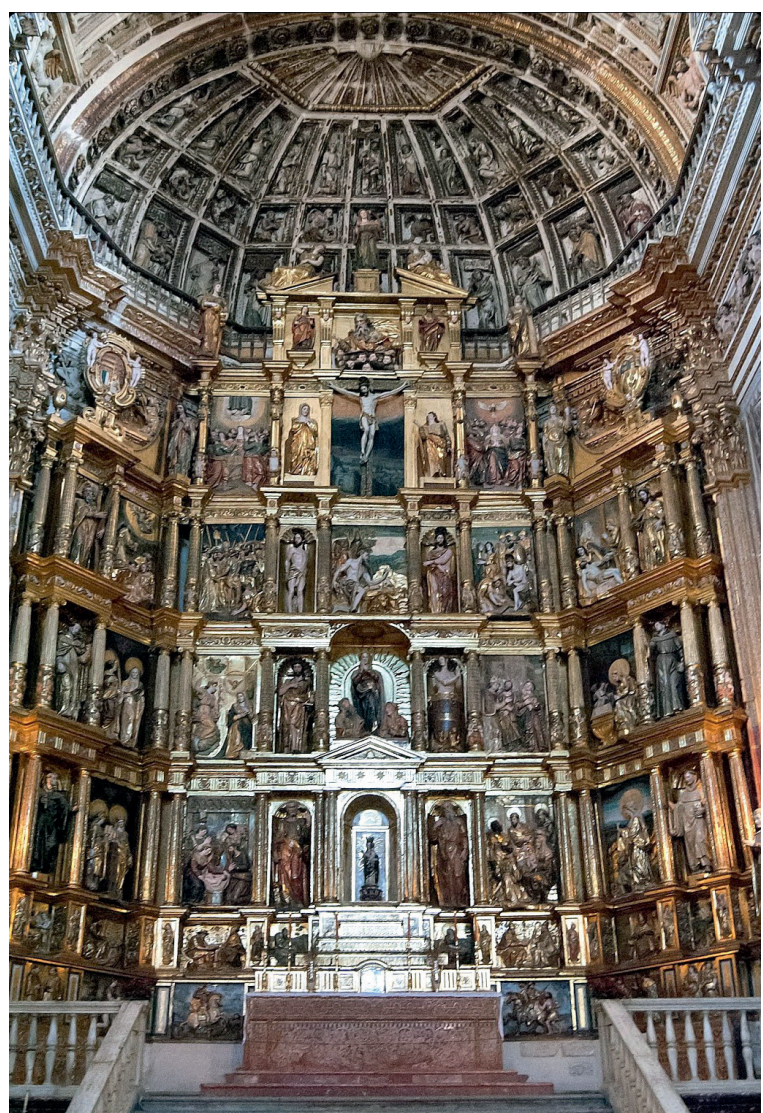

91. Lázaro de Velasco, Pedro de Orea, Juan Bautista Vázquez el Mozo, Melchor Turín, Pablo de Rojas et al., retablo mayor, a partir de 1579, Granada, monasterio de San Jerónimo fe, como el misterio eucarístico, amén de impulsar el culto a la Virgen, a los santos y a las reliquias. Pero, en definitiva, la valoración positiva de tales representaciones plásticas y la eficacia de su utilización - tan contundentemente negadas por los protestantes como defendidas por el Concilio de Trento - conducen a una extraordinaria demanda de imágenes, cuya proliferación no hará sino progresar con el tiempo, siendo objetos de veneración tanto en el ámbito interno de las iglesias, oratorios y conventos, cuanto en el viario urbano, a través de las procesiones.

Como es bien sabido, durante el último tercio del siglo XVI floreció en España la generación de los romanistas, cultivando un concepto heroico de las formas derivado de la plástica de Miguel Ángel. Juan de Arfe, en el libro segundo de su De varia commensuración para la esculptura y architectura (1585), ya ponía de relieve el papel jugado por Gaspar 
Becerra en este proceso, al traer de Italia "la manera que aora está introduzida entre los más artífices, que es las figuras compuestas de más carne que las de Berruguete"22, juicio que más tarde ampliaría Pacheco en su Arte de la pintura, su antigüedad y su grandeza al declarar que "Gaspar Becerra quitó a Berruguete gran parte de la gloria que había adquirido, siendo celebrado no sólo en España, pero en Italia, por haber seguido a Micael Ángel y ser sus figuras más enteras y de mayor grandeza. Y así imitaron a Becerra y siguieron su camino los mejores escultores y pintores españoles... y la manera suya, como reina de las demás, que mejor que ninguno aprehendió del divino Micael Ángel, lo levanta a tan alto grado" ${ }^{23}$. Se prefiere, por tanto, la monumentalidad de la figura humana, tratada según lo hace Becerra en clave triunfalista, con amplitud de masas y volúmenes, como símbolo de la grandeza moral del personaje representado ${ }^{24}$, en contraposición a los tipos más enjutos y nerviosos de Alonso Berruguete, quien había sido uno de los pioneros a la hora de introducir en la escultura española los ecos del manierismo florentino.

Para ilustrar el triunfo del vocabulario miguelangelesco en la escultura devocional española de este momento, acudimos a sendos ejemplos pertenecientes a la iconografía de la Virgen del Rosario, que tanto éxito obtuvo a raíz de la victoria de Lepanto, convirtiéndose la Orden de Predicadores y las cofradías instituidas bajo su égida en las principales difusoras de esta advocación. La primera se debe al maestro abulense afincado en Sevilla Jerónimo Hernández, quien la tallaría en torno a 1575-1578 para el convento dominico de San Pablo, presidiendo su altar mayor, aunque tres siglos más tarde se trasladó a la parroquia de Santa Cruz, en la capital hispalense (il. 92). Se muestra la Virgen sedente, cuya cabeza velada y peinada con raya central se nos brinda como la expresión renaciente de una matrona de la antigüedad clásica, presentando al hercúleo Niño Jesús erguido y ascendiendo sobre su rodilla derecha. Su modelo más cercano me parece la Madonna del Parto que labró en mármol Jacopo Sansovino para la iglesia romana de San Agustín, hacia 1521. La segunda fue contratada por el vasco Juan de Anchieta en 1586 para la cofradía rosariana de la parroquia de la Asunción de Navarrete, en La Rioja. En este caso, María aparece erguida, llevando al corpulento y desnudo Niño Jesús sobre su brazo izquierdo, al tiempo que sostienen ambas figuras unos rosarios de gruesas cuentas talladas en la propia madera, como también lo están la esfera del mundo bajo el pie izquierdo del divino infante, el libro

22 J. Arphe y Villafañe, De varia commensuración para la esculptura y architectura, Sevilla 1585, lib. II, a. 2v.

23 F. Pacheco, Arte de la pintura, su antigüedad y su grandeza (1649), ed. B. Bassegoda i Hugas, Madrid 2001, p. 349.

24 M. Serrano Marqués, Gaspar Becerra y la introducción del romanismo en España, "Boletín del Museo e Instituto Camón Aznar" 1999, no. 78-79, p. 207-240. 
que sujeta su madre en la diestra y la corona que esta luce sobre su testa, de nítida filiación clasicista, quizás tomada, como en el caso sevillano, de prototipos de Miguel Ángel, como el que ofrece en su Madonna del Silencio, popularizada y difundida a través del grabado de Philippe de Soye (1538).

La finalidad eminentemente doctrinal, pedagógica y persuasiva que justifica la existencia de la imaginería religiosa, y su confrontación con la realidad tangible, abonará el terreno que la conducirá por la senda del primer naturalismo barroco. En la consecución de este propósito se asigna a la policromía un papel fundamental, tanto si la imagen está tallada en madera,

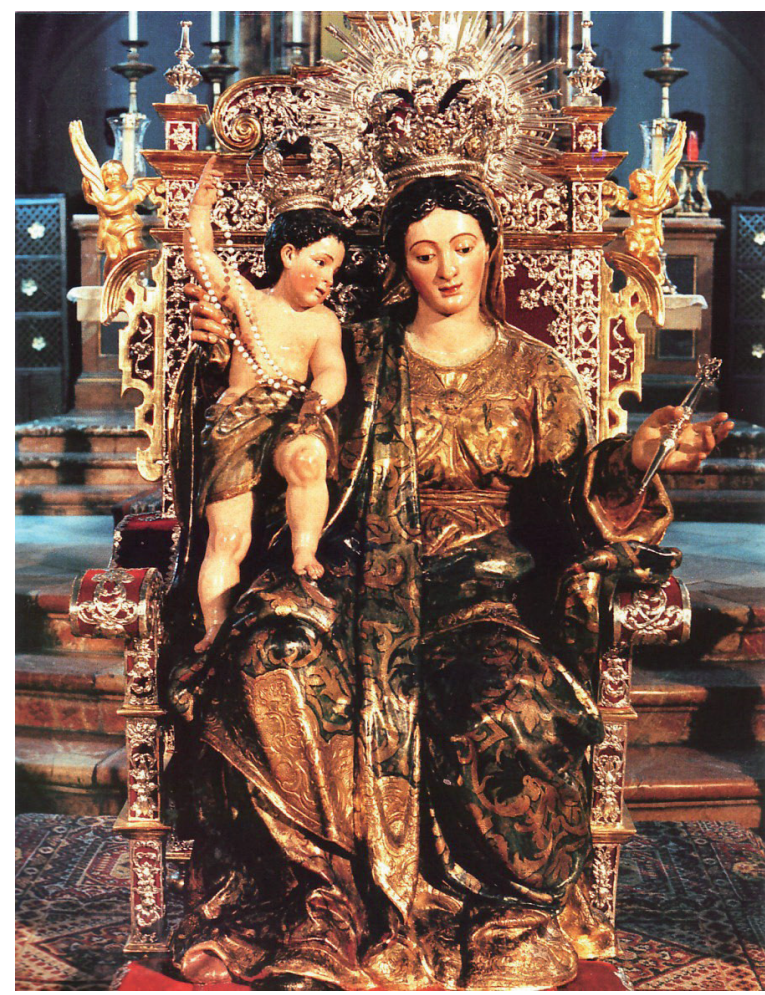

92. Jerónimo Hernández, Virgen del Rosario, hacia 1575-1578, Sevilla, parroquia de Santa Cruz como si está modelada en barro o confeccionada en pasta.

Escribía Pacheco que la pintura era "vida de la escultura", y que toda imagen estaba "necesitada de ella para conseguir la verdadera imitación de lo natural, y que según el grado en que estuviere el pintor, así ayudará la escultura bien o mal"25, dando a entender que una buena policromía subrayaba e incluso mejoraba los valores del modelado escultórico, otorgándole su última perfección, y que, por el contrario, una deficiente capa pictórica podía desvirtuarlos, disminuyendo su categoría artística.

Un ejemplo temprano de estas pretensiones estéticas lo tenemos en la cabeza degollada de San Juan Bautista que realizara en terracota Gaspar Núñez Delgado (c. 1555-1606) en 1591 - hoy en el Museo de Bellas Artes de Sevilla - donde utiliza el valor dramático que provoca tal asunto para hacer visible sus conocimientos anatómicos. El propio Núñez Delgado cultivaría con repetido éxito dos temas de la Pasión que, por su propio contenido sensible de

25 F. Pacheco, Arte de la pintura..., op. cit., p. 89. 


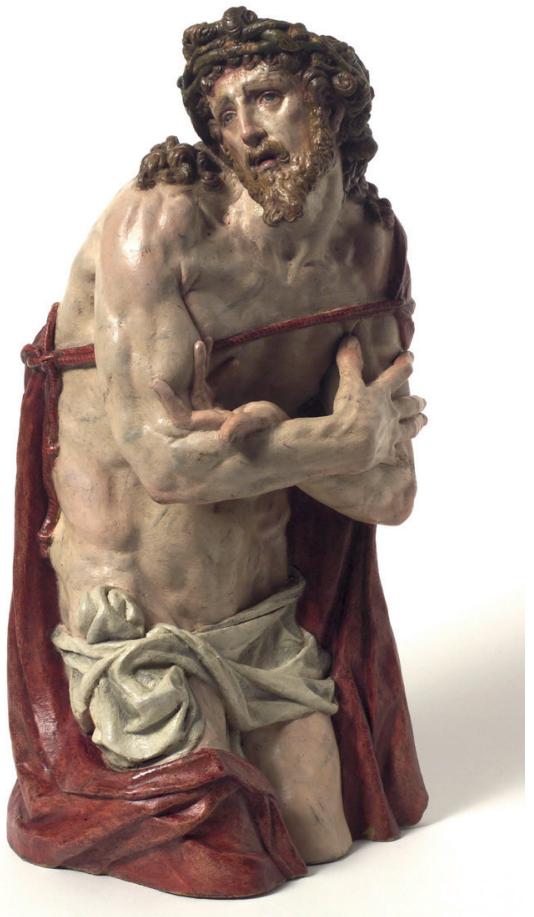

93. Gaspar Núñez Delgado, Ecce Homo, hacia 1590-1600, Granada, Instituto Gómez-Moreno tono patético, favorecieron el inicio de esta espiral naturalista en el contexto de la escultura sevillana. Nos referimos, por un lado, a los Ecce Homos en barro cocido y policromado, capaces de transmitir una intensa emotividad expresiva: los hay que presentan un formato de más de medio cuerpo, con los brazos cruzados ante el pecho, como los del convento de la Concepción de La Paz (Bolivia) y el del Instituto Gómez-Moreno de Granada (il. 93), en sugestivo paralelo a los que poco más tarde realizarían en esta última ciudad los hermanos García ${ }^{26}$; otros son bustos cortados por debajo del cuello, que apenas incluyen un fragmento de clámide, constituyendo una larga serie, ejemplificada en las cabezas que se conservan en el Museo Nacional de Escultura de Valladolid, iglesia de San Nicolás de Madrid, Capilla Real de Sevilla, parroquias hispalenses del Sagrario y Santa Cruz, convento de San Antón de Granada o Museo de Bellas Artes de esta última ciudad ${ }^{27}$. De otro lado, mencionaremos los Crucificados expirantes

tallados en marfil, de pequeño formato y apurado estudio anatómico, entre los que se cuentan los del Museo Bello de Puebla en México (1585), Palacio Real de El Pardo (1589) o el ya manifiestamente prebarroco del Museo de Indianápolis (1599), de los que debió sentirse especialmente orgulloso, por cuanto se preocupó de firmarlos y fecharlos en un lugar bien visible, y que fueron ampliamente demandados por una selecta clientela ${ }^{28}$, despertando

26 J. J. López-Guadalupe Muñoz, Forma y expresión en los inicios del naturalismo en la escultura granadina. Lecturas y relecturas sobre los Hermanos García, [en:] La escultura del primer naturalismo en Andalucía e Hispanoamérica..., op. cit., p. 207-238.

27 L. Luna Moreno, Gaspar Núñez Delgado y la escultura de barro cocido en Sevilla, "Laboratorio de Arte" 2008-2009, no. 21, p. 379-394.

28 M. Estella Marcos, La escultura barroca de marfil en España. Las escuelas europeas y las coloniales, II, Madrid 1984, p. 13-18; eadem, Un Cristo de marfil inédito de Gaspar Núñez Delgado, "Archivo Español de Arte" 1986, no. 234, p. 192-196. 
incluso la admiración de Juan Martínez Montañés, que en 1590 los tomó como referente para un encargo, del mismo género y material, recibido del presbítero Nicolás Monardes, cuyo paradero se desconoce.

El elegante clasicismo espiritualizado del que hace gala Montañés encuentra el camino de la expresión naturalista, aun escogiendo siempre sus rasgos más bellos, en el formidable Crucificado de la Clemencia (1603-1606) de la catedral sevillana, que dialoga abiertamente con el fiel arrodillado a sus plantas, tal como lo ajustara con su comitente, el arcediano de Carmona Mateo Vázquez de Leca, a quien manifestó que tenía "gran deseo de acavar e hacer una pieça semejante a ésta para que quede en España y no se lleve a las yndias ni a otras partes y se sepa el maestro que la hizo para gloria de Dios". Para la colocación de sus pies cruzados y atravesados por sendos clavos se apoyó, desde el punto de vista literario, en las Revelaciones de Santa Brígida de Suecia, sin poderse obviar la sugestión formal que debió producirle el modelo, entonces considerado de Miguel Ángel, que había sido traído desde Roma a Sevilla en 1597 por el platero Juan Bautista Franconio, vaciado en bronce y después multiplicado en cruces de orfebrería ${ }^{29}$, con el que comparte su estilizada verticalidad, aunque Montañés cambió la disposición de sus piernas, colocando la derecha sobre la izquierda. Por su parte, el Niño Jesús tallado para la Hermandad Sacramental del Sagrario de la catedral de Sevilla (1606-1607) encarna otro acierto pleno en la producción montañesina ${ }^{30}$, consagrando un modelo que de inmediato obtuvo el refrendo popular, siendo objeto de innumerables reproducciones en madera y vaciados de plomo, estaño o peltre, destinadas a satisfacer una intensa y extensa demanda que llegó hasta el Nuevo Mundo (il. 94). Resulta portentoso el tratamiento blando de la anatomía infantil, que describe un airoso y rítmico contraposto de estirpe clásica. En actitud deífica, el pequeño Jesús se yergue sobre un cojín para bendecir con la diestra, al tiempo que su mano izquierda fue concebida originalmente para portar una cruz de ébano de tipología arbórea, aunque ahora suele sujetar un cáliz-ostensorio de filigrana. Nos conmueve la apacible dulzura de su rostro, enmarcado por una cabellera de ensortijados bucles, muy del gusto del maestro alcalaíno. Por lo que respecta a sus esculturas marianas, realizó algunas interpretaciones memorables de la Virgen Madre, como la del

29 F. Pacheco, Arte de la pintura..., op. cit., p. 725. Después se demostraría que, en realidad, era obra de su discípulo el arquitecto y escultor Giacomo del Duca. C. Heredia, La recepción del clasicismo en la platería española del siglo XVI, [en:] Congreso Internacional "Imagines": La Antigüedad en las artes escénicas y visuales, ed. M. J. Castillo Pascual, Logroño 2008, p. 458-459.

30 E. Gómez Piñol, El Niño Jesús de la Sacramental del Sagrario hispalense: introducción al estudio de la génesis de un prototipo distintivo de la escultura sevillana, [en:] Actas del Coloquio Internacional "El Niño Jesús y la infancia en las artes plásticas, siglos XV al XVII", ed. R. Ramos Sosa, Sevilla 2010, p. 15-104. 
monasterio de San Isidoro del Campo (1609-1610) o la que, bajo el título de la Cinta, se le atribuye acertadamente en la catedral de Huelva (1606-1609). Pero, sin lugar a dudas, fue el candente tema de la Inmaculada Concepción el que le permitió plasmar algunas de sus obras más carismáticas, pues partiendo de versiones manieristas granadinas y sevillanas, llegó a fijar todo un prototipo que siguieron muchos escultores de su entorno, ofreciéndonos su primera exégesis en la aniñada y poética Inmaculada de la parroquia de El Pedroso (1606-1608), en la provincia de Sevilla.

Este precoz sentimiento barroco lo encontramos formulado, dentro del importante foco escultórico granadino, en las últimas creaciones de Pablo de Rojas (1549-1611) ${ }^{31}$ - extraordinarias sus series iconográficas de temáticas pasionista y mariana - y en las primeras de Bernabé de Gaviria (1577-1622) ${ }^{32}$, quien en su excelente apostolado (en realidad le pertenecen diez de los doce, realizados en dos fases: 1611-1613 y 1616-1617) de la capilla mayor de la catedral de Granada nos ofrece uno de los más felices conjuntos de la plástica andaluza e incluso española de la segunda década del siglo XVII.

\section{La escultura procesional}

Los escritos de nuestros ascetas y místicos del siglo XVI persiguieron actuar sobre sus lectores, excitándoles sensorialmente hasta hacerles experimentar que se encontraban ante la escena o acontecimiento a meditar, y todo para moverles a la devoción. Esta vía de la meditación realista, cuyos verdaderos creadores fueron los franciscanos, genera una suerte de imaginería mental que alcanza tintes de gran intensidad dramática y expresiva cuando se trata de rememorar los pasos de la Pasión de Cristo, en lo que fray Luis de Granada fue un auténtico maestro ${ }^{33}$.

Para estos autores, el mundo sensorial es valorado no tanto por sí mismo, cuanto como estímulo capaz de mover el alma hacia Dios. En este sentido, la plástica escultórica jugará un protagonismo esencial para desatar en el devoto esa desbordante emoción comunicativa que alcanza su cenit en los días de Semana Santa, durante las estaciones de las cofradías de penitencia, cuando las imágenes que representan a Cristo en los diferentes momentos de su pasión y muerte, y a la Virgen en sus dolores y soledad, se encuentran a pie de calle con el fiel cristiano, haciéndole copartícipe de sus padecimientos. Puede decirse que estas

31 J. J. López-Guadalupe Muñoz, Pablo de Rojas, encrucijada de las escuelas andaluzas, [en:] La escultura del primer naturalismo en Andalucía e Hispanoamérica..., op. cit., p. 137-174.

32 L. Gila Medina, Bernabé de Gaviria: continuación y ruptura de los ideales de Rojas, [en:] La escultura del primer naturalismo en Andalucía e Hispanoamérica..., op. cit., p. 175-206.

33 E. Orozco Díaz, Introducción al Barroco, I, Granada 1988, p. 261-262. 


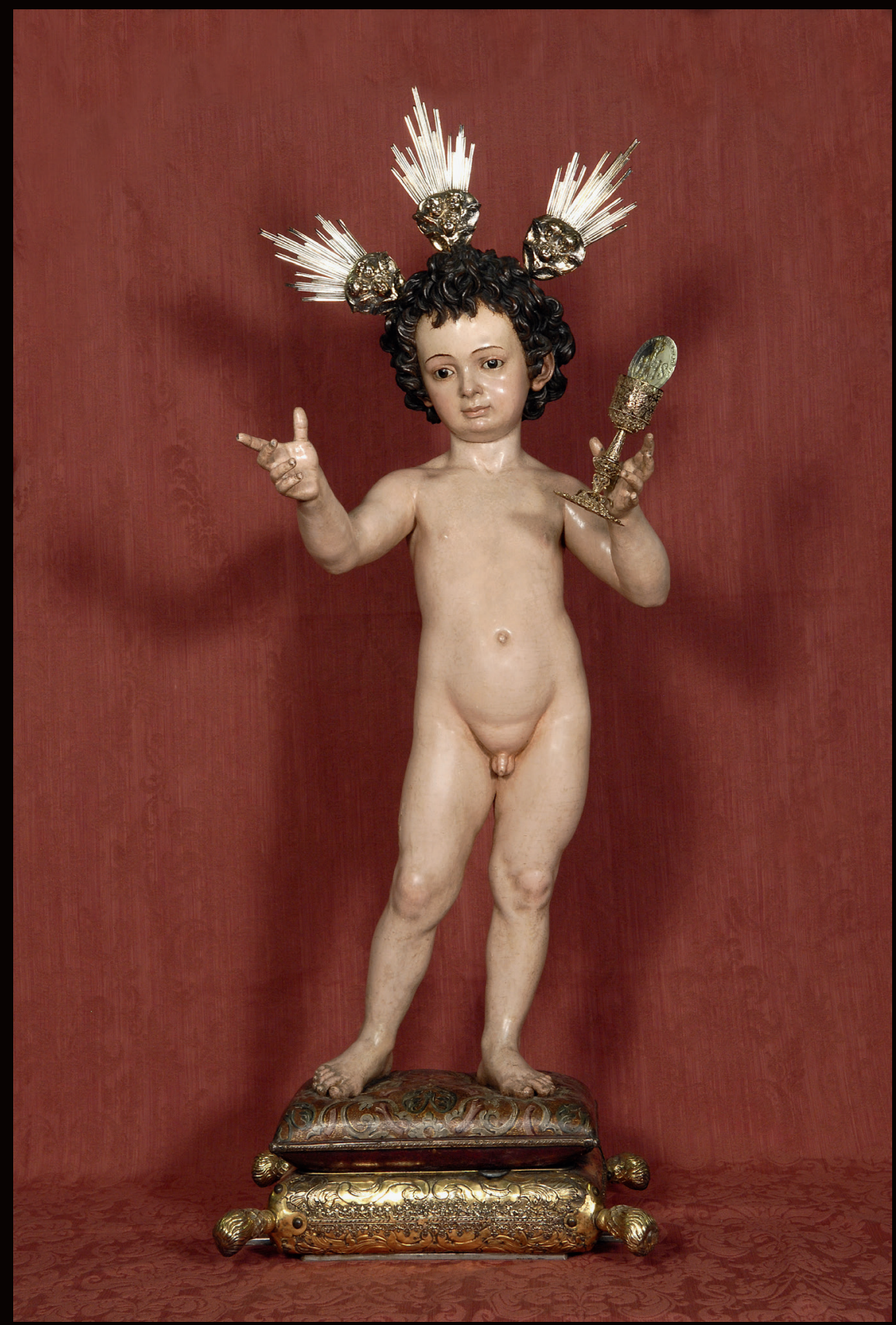

94. Juan Martínez Montañés, Niño Jesús, 1606-1607, Sevilla, parroquia del Sagrario de la catedral 
procesiones, acompañadas de disciplinantes, fueron un instrumento que utilizó la Iglesia con una intención socio-religiosa, adoctrinadora y propagandística, dirigida a todos los estamentos sociales, para recordarles el supremo poder de la religión como único medio de salvación. Esta práctica de la flagelación pública, tan espectacular como cruenta, fue debidamente alentada a través de los sermones y pláticas cuaresmales, que reforzaban en la psicología de los fieles un sentimiento de culpa por los pecados cometidos y el temor a los castigos eternos, provocando su arrepentimiento y mortificación.

El disciplinante, en toda la ferocidad y violencia sanguinaria que le imprime su práctica devocional, es fiel reflejo de Cristo en el paso de su flagelación, tal como es descrito por los literatos y predicadores del momento. Igual sucede con aquel que destroza sus hombros al portar una cruz, imitando a Jesús Nazareno en su camino hacia el Calvario. Y esa misma conmovedora impresión es la que tratan de transmitir los escultores en las imágenes de temática pasionista que les son encargadas expresamente por las cofradías de penitencia españolas, donde a medida que nos adentremos en el siglo XVII se apuntará hacia un realismo más cruel, con una recreación morosa en los detalles de dolor que se resaltan con vivos gestos de imploración, desmayo, tristeza y sufrimiento ${ }^{34}$.

Me centraré en algunos hitos especialmente significativos de la escultura procesional en Valladolid ${ }^{35}$ y Sevilla ${ }^{36}$, dos ciudades donde la celebración de la Semana Santa sigue gozando hoy de la máxima pujanza y vitalidad. Aunque las más antiguas de sus cofradías penitenciales, que son las de la Vera Cruz, se remontan a la segunda mitad del siglo XV, lo cierto es que las fundaciones se multiplicaron a lo largo de la siguiente centuria, y por consiguiente, también hubieron de proliferar los encargos de las imágenes a las que rendían culto público.

El incremento exponencial que conoce la devoción por María en la España de la Contrarreforma se encuentra detrás de la comisión que hacia 1570 le hiciera a Juan de Juni la cofradía vallisoletana de las Angustias para tallar su efigie titular, una suerte de Piedad que prescinde de la figura de Cristo sobre su regazo (il. 95). Su expresión de dolor se transmite con particular realismo en la torsión de la figura y la presión de los dedos de su mano derecha, que se estrechan contra el pecho. Se trata de una escultura perfectamente trabajada desde todos los ángulos, ahuecada para eliminar peso con vistas a su uso procesional y de tamaño algo superior al natural.

34 J. J. Martín González, El arte procesional del barroco, Madrid 1993, passim.

35 Pasos restaurados, ed. J. Urrea Fernández, cat. exp., Valladolid, Museo Nacional de Escultura, Valladolid 2000, passim; J. I. Hernández Redondo, Escultura procesional en Valladolid, [en:] Conocer Valladolid. III Curso de patrimonio cultural, ed. C. Sanz Mínguez, Valladolid 2010, p. 127-140.

36 J. M. González Gómez, J. Roda Peña, Imaginería procesional de la Semana Santa de Sevilla, Sevilla 1992, passim. 


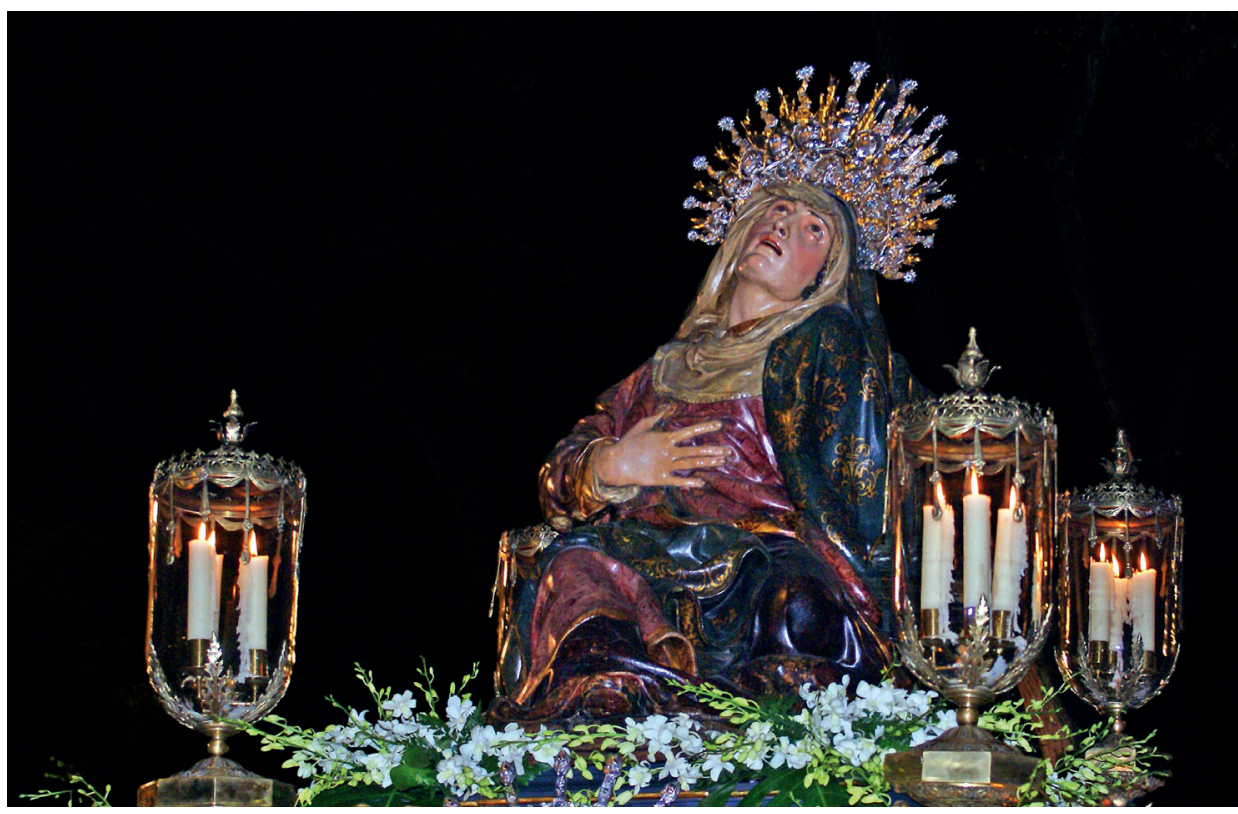

95. Juan de Juni, Virgen de las Angustias, hacia 1570, Valladolid, iglesia de Nuestra Señora de las Angustias

El más antiguo paso procesional compuesto de varias figuras que se conserva en la Semana Santa de Valladolid es el de la Entrada de Jesús en Jerusalén. Para procurar su liviandad, amén de su reducido formato, los protagonistas de tan alegre y bulliciosa escena están compuestos por un armazón lígneo recubierto con telas encoladas, mientras que su cabeza, manos y pies se tallaron en madera. Los tres personajes vestidos con jubón, calzas y botas, se pueden fechar claramente a mediados del siglo XVI, atribuyéndose al escultor Francisco Giralte, pero las restantes imágenes, incluido el grupo de Jesús montado sobre el asno con acompañamiento de la borriquilla, parecen fruto de una reforma posterior, de hacia 1600.

Con el paso de la Elevación de la Cruz, obra de Francisco Rincón (c. 1567-1608) (7) $^{37}$ 1604 , comienza un verdadero siglo de oro para la escultura procesional vallisoletana. Las figuras, talladas en madera policromada y de un tamaño cercano al natural, conforman una

37 J. Urrea, El escultor Francisco Rincón, "Boletín del Seminario de Estudios de Arte y Arqueología” 1973, no. 39, p. 491-500; E. García Martín, Los escultores Francisco del Rincón y Gregorio Fernández, Valladolid 2001, passim. Los pasos que estudiaremos de Rincón y Fernández se exponen en el Museo Nacional de Escultura de Valladolid. 


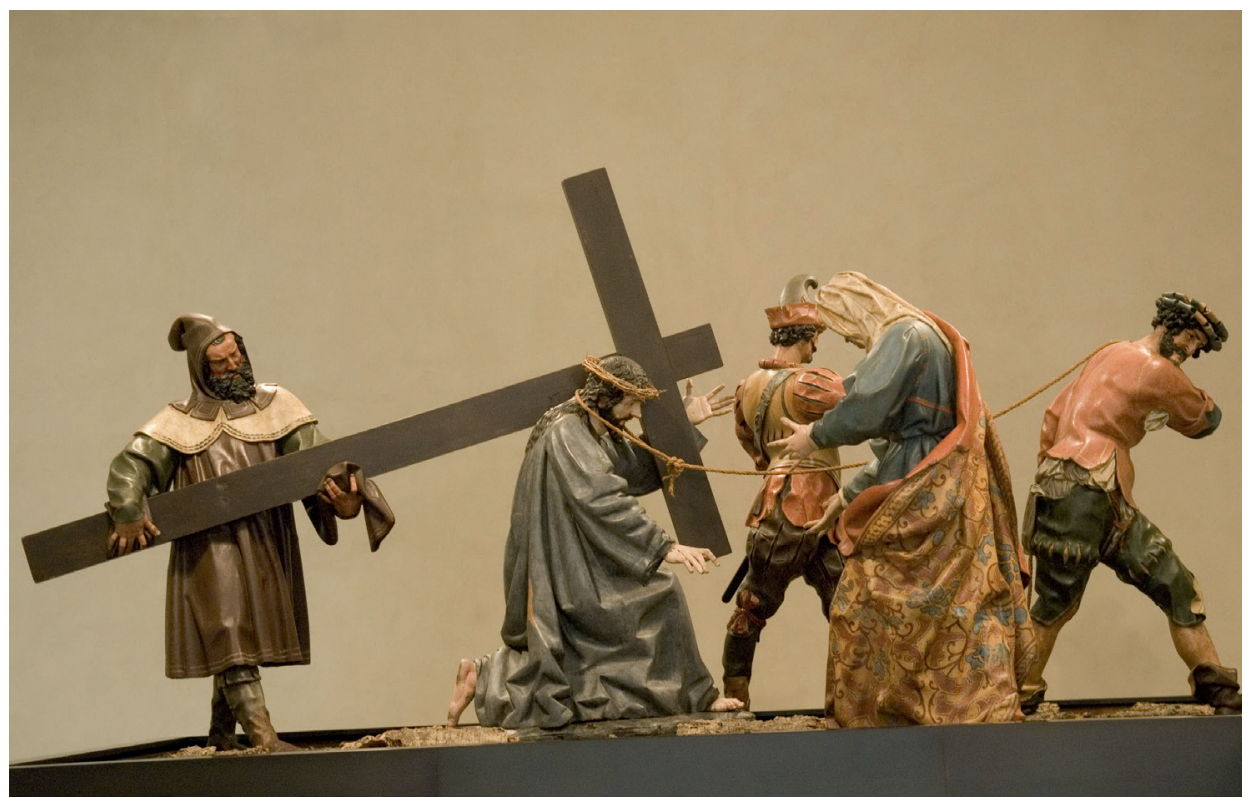

96. Gregorio Fernández, Camino del Calvario, 1614, Valladolid, Museo Nacional de Escultura

escena de elevada complejidad que muestra, en su habilidosa resolución, puntos de contacto con la estampa del mismo tema abierta en 1590 por Aegidius Sadeler II sobre composición de Christoff Schwartz, sin disminuir por ello la capacidad creativa de su autor. La visión de costado ofrece una composición diagonal, aún más valorada por la exagerada curvatura del cuerpo de los dos sayones que tiran esforzadamente de las cuerdas para izar la cruz.

La evolución de este género continuó con Gregorio Fernández $(1576-1636)^{38}$, que había trabajado como oficial en el taller de Rincón. Llegó a contratar hasta seis conjuntos procesionales de distintos episodios de la Pasión, destinados a cuatro cofradías de Valladolid, solucionando con éxito difíciles retos compositivos. La serie comenzó con la donación en 1612, por parte del gremio de pasamaneros, de un Crucificado y dos sayones para la Hermandad de Jesús Nazareno, completado cuatro años más tarde con otros tres esbirros, conformando todos ellos el pasaje de "Sed Tengo" en una composición piramidal donde

38 J. J. Martín González, El escultor Gregorio Fernández, Valladolid 1980, passim; Gregorio Fernández y la Semana Santa de Valladolid, ed. E. García de Wattenberg, cat. exp., Valladolid, Museo Nacional de Escultura, Madrid 1986, passim; I. del Río, Gregorio Fernández y su escuela, Madrid 1992, passim; Gregorio Fernández, 1576-1636, ed. J. Urrea, Madrid 1999, passim; Gregorio Fernández: la gubia del barroco, eds. A. Álvarez Vicente, J. C. García Rodríguez, Valladolid 2009, passim; R. de Orueta, Gregorio Fernández: la expresión de dolor en la escultura castellana, Valladolid 2013, passim. 
las figuras hacen gala de unas actitudes dinámicas, pero perfectamente equilibradas. El mismo año de la muerte de El Greco, en 1614, concertó con la antigua Cofradía de Nuestra Señora de la Pasión el paso del Camino del Calvario, que incorpora piezas de sobresaliente calidad, como el Cirineo, la Verónica, el sayón que tira de la cuerda y el que abre camino tocando la trompeta (il. 96). En estos últimos personajes, de zafia naturaleza, parece depositar Fernández toda la maldad humana, acudiendo a gestos descompuestos, expresiones hostiles, miradas torvas y ademanes vulgares.

Pasando ahora a Sevilla ${ }^{39}$, el Cristo de la Expiración de la capilla del Museo de Bellas Artes representa con singular verismo el momento del espasmo agónico que hace contorsionar sus miembros como una llamarada entre estertores de dolor. Realizado por Marcos de Cabrera ${ }^{40}$ en diciembre de 1575, el mismo año en que se erigió canónicamente su cofradía por el gremio de maestros plateros, es la primera representación, a tamaño natural, de Cristo expirante en el seno de la escultura sevillana, al menos que se haya conservado. Para la composición serpentinata de su cuerpo se apunta como posible fuente de inspiración para su autor el Crucifijo que dibujó Miguel Ángel para Vittoria Colonna en torno a 1541 (British Museum), muy divulgado en Europa a partir del grabado de Giulio Bonasone. La ductilidad del material empleado, la pasta, sirve a Cabrera para acentuar las curvas y dislocar dramáticamente las extremidades inferiores, abocetando ciertas partes de su anatomía. Debe aclararse que tanto su corona de espinas como el paño de pureza, de atrevido dinamismo, no son más que postizos añadidos por Manuel Gutiérrez Reyes en 1893 y 1895.

Temprano y justo renombre adquirió el formidable Niño Jesús que Jerónimo Hernández esculpiera para la Cofradía del Dulce Nombre de Jesús y Primera Sangre de Nuestro Señor Jesucristo, residente en la actual parroquia de Santa María Magdalena. Fechable hacia 1580, puede considerarse, en el ámbito escultórico sevillano, como pionero en su género, componiéndose su figura con acusado contrapposto de evocación praxiteliana. Desde el punto de vista iconográfico, se especula con que Hernández pudiera haberse basado en el modelo pictórico que Pedro de Villegas Marmolejo ofrece en el ático del retablo de la Visitación de la catedral hispalense. Sabemos que esta imagen, al menos desde comienzos del siglo XVII, desfilaba en Semana Santa bajo un palio sostenido por seis varas de plata. Fray Francisco

39 Para esta etapa germinal de la imaginería procesional de la Semana Santa de Sevilla, véase: J. Roda Peña, La escultura sevillana a finales del Renacimiento y en los umbrales del Naturalismo, [en:] La escultura del primer naturalismo en Andalucía e Hispanoamérica..., op. cit., p. 294-295.

40 Su trayectoria vital está documentada desde 1565 hasta 1601, acreditándosele una estancia en Colombia entre 1582 y 1590. P. F. Amador Marrero, J. C. Pérez Morales, El sevillano “capitán” Marcos de Cabrera: personaje enigmático, notable escultor. Revisión histórico-artística y técnica, "Atrio" 2007-2008, no. $13-14$, p. 87-98. 
Ramírez de Solórzano, en su historia manuscrita del convento de San Pablo de Sevilla, redactada en 1625, nos dice "que es una hechura singular, con un semblante sumamente devoto y penitente cuando se viste de Pasión, y muy alegre y agraciado en tiempo de gloria, que parece ser distinto siendo uno mismo" ${ }^{41}$. Esa misma hermandad del Dulce Nombre de Jesús, a fin de celebrar en Pascua florida una procesión triunfal presidida por una efigie del Resucitado, encargó el 8 de mayo de 1582 a Jerónimo Hernández una escultura en madera policromada de tal iconografía, que habría de estar ahuecada internamente, formando un solo bloque con su peana. Se inspira claramente en el Resucitado que cinceló en mármol Miguel Ángel para Santa María sopra Minerva de Roma, que Hernández posiblemente conocería a través del grabado de Nicolás Beatrizet.

El sublime Nazareno de Pasión, venerado en la capilla sacramental de la iglesia colegial del Divino Salvador, es la única escultura procesional de la Semana Santa de Sevilla que se puede adjudicar con seguridad a Martínez Montañés, hacia 1610-1615 (il. 97). Imagen para vestir, se ha concentrado su fuerza expresiva en la mansedumbre de su rostro, de inefable ternura en el perfecto acabado de su talla, admirando la suprema elegancia de sus manos, cuyos dedos apenas rozan el madero, y el sentido itinerante impreso a su pausado caminar, con el pie izquierdo firmemente asentado sobre la peana rocosa y el diestro levantado, permaneciendo el dedo primero como único punto de apoyo. El mercedario fray Juan Guerrero, a mediados del siglo XVII, nos deja consignado que "La... imagen... del santo Cristo de la pasión... es admiración el ser en un madero haber esculpido obra tan semejante al natural; no encarezco ni podré lo prodigioso de esta hechura porque cualquier encarecimiento será sin duda muy corto, solo baste decir es obra de aquel insigne maestro Juan Martínez Montañés, asombro de los siglos presentes y admiración de los por venir como lo declaran las obras que hoy se hallan de su mano tan celebradas y aplaudidas por todo género de gentes..."42.

\section{El Greco, escultor}

En su Arte de la pintura, su antigüedad y su grandeza (1649), Francisco Pacheco nos ofrece un valioso testimonio a propósito de la visita que en 1611 le hizo al Greco en Toledo, quien con la mayor naturalidad y confianza le mostró "una alhazena de modelos de barro de su mano, para valerse dellos en sus obras”. Por otro lado, en el primer inventario de sus

41 Citado por: J. Bermejo y Carballo, Glorias religiosas de Sevilla, Sevilla 1882, p. 90-91.

42 J. Roda Peña, La imagen de Nuestro Padre Jesús de la Pasión: un modelo para la iconografía del Nazareno en Sevilla, [en:] Actas del Congreso Internacional "Cristóbal de Santa Catalina y las Cofradías de Jesús Nazareno", II, Córdoba 1991, p. 675-686. 


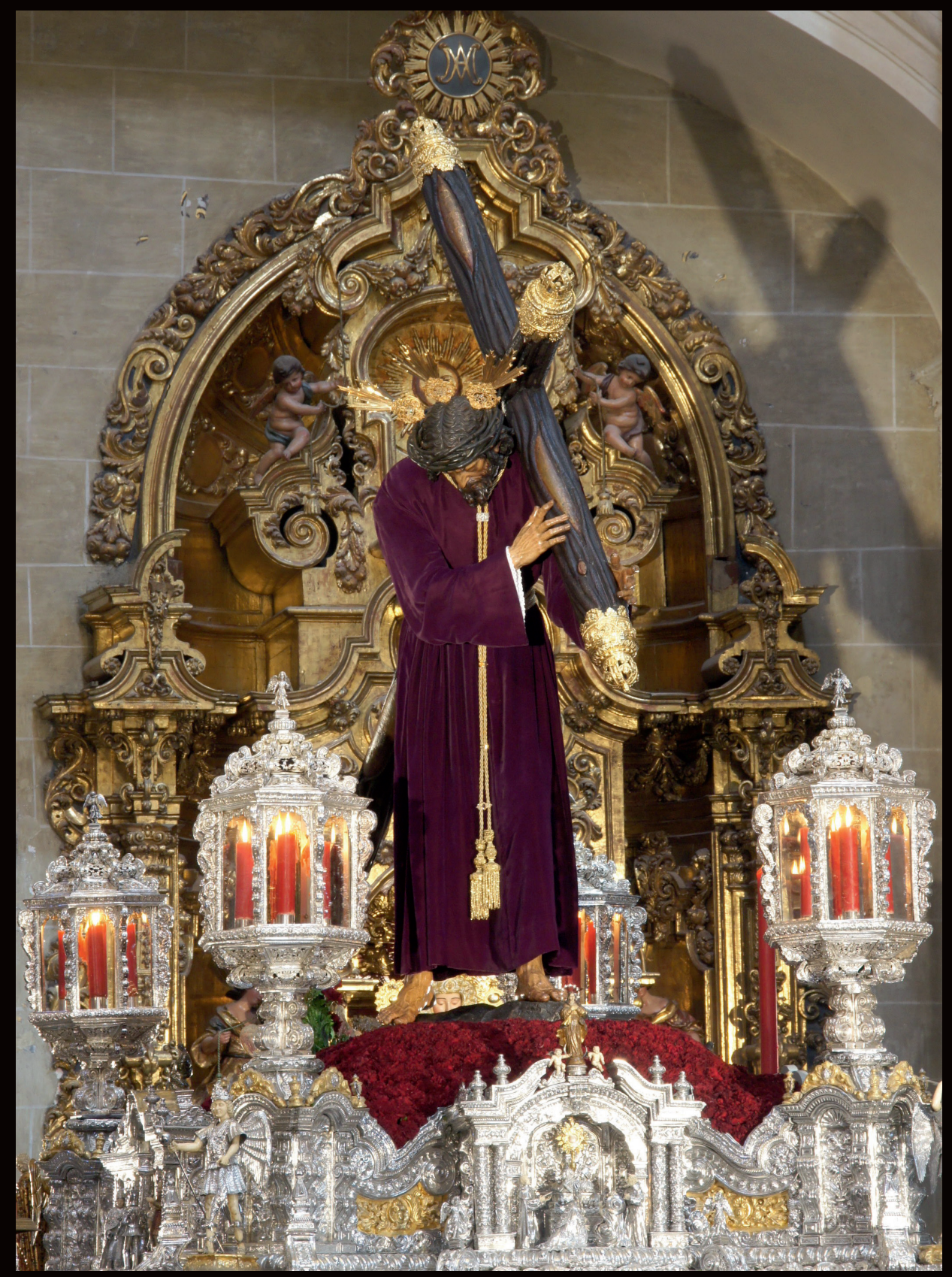

97. Juan Martínez Montañés, Jesús de la Pasión, hacia 1610-1615, Sevilla, iglesia colegial del Divino Salvador 
bienes, elaborado por su hijo Jorge Manuel en 1614, se registran veinte modelos de yeso y treinta más de barro y cera - susceptibles estos últimos de experimentar un sinnúmero de transformaciones - comprobatorios de que habitualmente modelaba con carácter previo las figuras de sus cuadros, procedimiento aprendido en Venecia con Tintoretto, sirviéndole para resolver con éxito ciertos aspectos dificultosos de la composición pictórica ${ }^{43}$.

Pero además, afirmar que El Greco cultivó el arte de la escultura, y no simplemente como un proceso intermedio en la ejecución de sus pinturas, es hoy por hoy una evidencia que está fuera de toda duda, aunque ciertamente dicha práctica haya merecido una cuota muy exigua en el reconocimiento de su genio. Para el cretense, tan admirador del Miguel Ángel dibujante y escultor, la escultura encarnaba un código expresivo tan válido y digno como cualquiera de las otras artes imitativas de la naturaleza, requiriendo de un proceso intelectual que sobrepasaba con mucho la aplicación de una técnica manual y de los procedimientos artesanales de un oficio meramente mecánico. El conocido episodio ocurrido con el marco de El Expolio, por el que se le pagaron 535 ducados, frente a los 317 correspondientes a la propia pintura, debieron convencerle de la rentabilidad que suponía que en sus futuros encargos también se le encomendara la ejecución de este género de ensambladuras con sus eventuales adornos figurativos.

Comenzaremos nuestro recorrido por el escueto legado de la obra escultórica de El Greco con el altorrelieve en madera policromada y pequeño formato de la Imposición de la casulla a San Ildefonso, que fue parte constitutiva del retablo presidido por el espléndido cuadro de El Greco que representa El Expolio de Cristo (1577-1579). A finales del siglo XVIII se desmontó la estructura original del conjunto hasta que, a comienzos del XX, se situó este grupo escultórico en su localización actual, bajo la mencionada pintura, en la sacristía de la catedral de Toledo. El milagro presenta a la Virgen María, descendida y sedente sobre un cúmulo de nubes y cabezas de querubes, acompañada por cuatro hermosos ángeles mancebos que le auxilian en el momento de la donación al santo arzobispo, quien la contempla de rodillas y orando. La casulla es la recompensa, el fruto espiritual por su defensa de la virginidad de la Madre de Dios, y los ángeles son los celestes cortesanos, fieles servidores que forman el cortejo de la Señora ${ }^{44}$.

El Cristo resucitado del Hospital Tavera, en Toledo, aparece enteramente desnudo, necesitado de un paño de pureza textil (il. 98). Este gusto por mostrar sin veladuras la belleza del cuerpo humano resulta un rasgo más italiano que español de su personalidad y obra,

43 Y. Kitaura, El proceder artístico de El Greco, "Boletín del Museo del Prado" 1986, no. 20, p. 85-93.

44 Ha sido restaurado en 2011 por el Instituto del Patrimonio Cultural de España (IPCE). R. López Torrijos, Iconografía de San Ildefonso desde sus orígenes hasta el siglo XVIII, "Cuadernos de Arte e Iconografía" 1988, no. 2, p. 165-212. 
que evidencia estar escasamente influenciada por el ambiente religioso imperante en la España de las últimas décadas del siglo XVI, que defendía a ultranza el decoro y propiedad de las imágenes sagradas ${ }^{45}$. De inmediato se advierte la proximidad entre esta pequeña escultura en madera policromada, terminada por El Greco en 1598, con el Resucitado que el candiota pintara entre 1597 y 1600 para el retablo mayor de la iglesia del Colegio de la Encarnación en Madrid, que hoy se expone en el Prado. La figura gloriosa de Jesús, limpia en su encarnadura de cualquier signo de dolor, parece avanzar hacia nosotros con paso firme y elegante distinción, en actitud de bendecirnos con serena divinidad. En realidad, la sensación que nos transmite de ingravidez corporal comulga perfectamente con el hecho de que fuera concebida para lucir suspendida sobre el manifestador en forma de templete que adorna todavía hoy el altar mayor de la iglesia hospitalaria, reafirmando así la doctrina fundamental de su presencia corpórea en la Eucaristía ${ }^{46}$.

Las esculturas que se le atribuyen con firmeza de Epimeteo y Pandora (c. 16001610), de poco más de cuarenta centímetros de altura, fueron adquiridas en 1945 por el V Conde de las Infantas, don Joaquín Pérez del Pulgar y Campos, siendo donadas al Museo Nacional del Prado por su viuda, doña Dolores Andrada y Pérez de Herrasti,

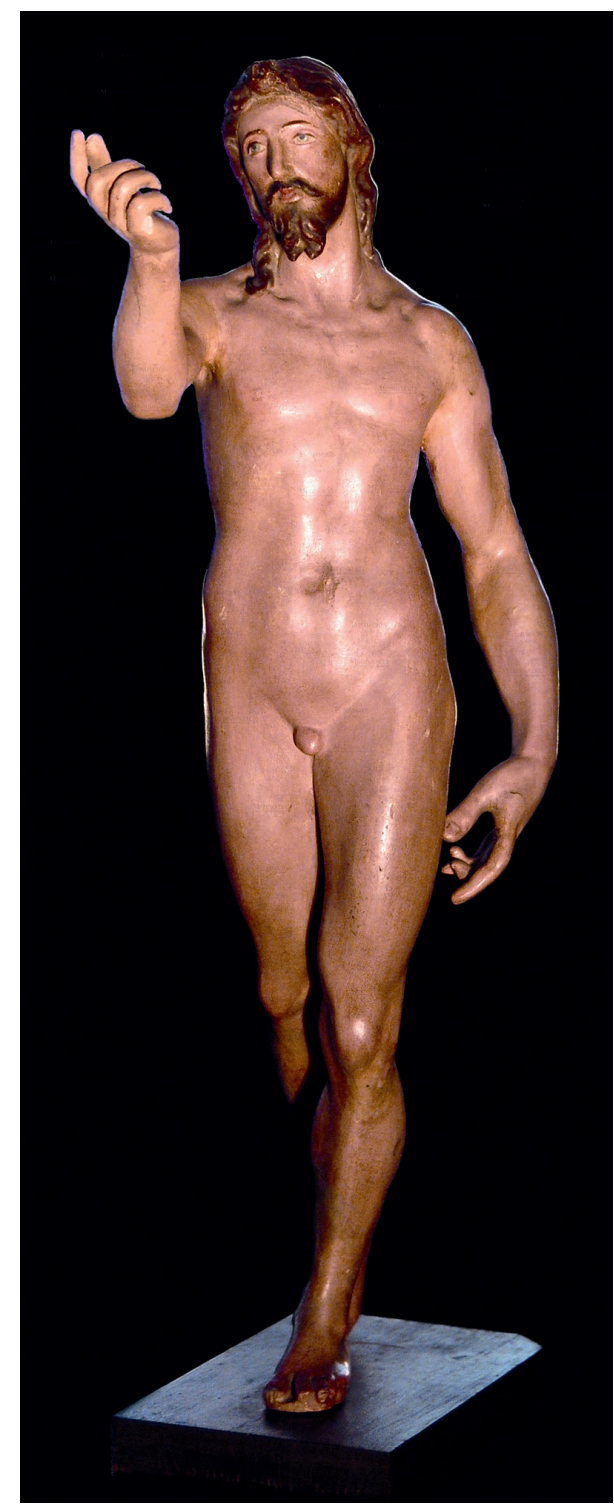

98. El Greco, Cristo Resucitado, 1598, Toledo, Hospital Tavera

45 F. Marías, A. Bustamante García, Las ideas artísticas de El Greco. Comentarios a un texto inédito, Madrid 1981, p. 206.

46 R. G. Mann, El Greco y sus patronos. Tres grandes proyectos, Madrid 1994, p. 114. 

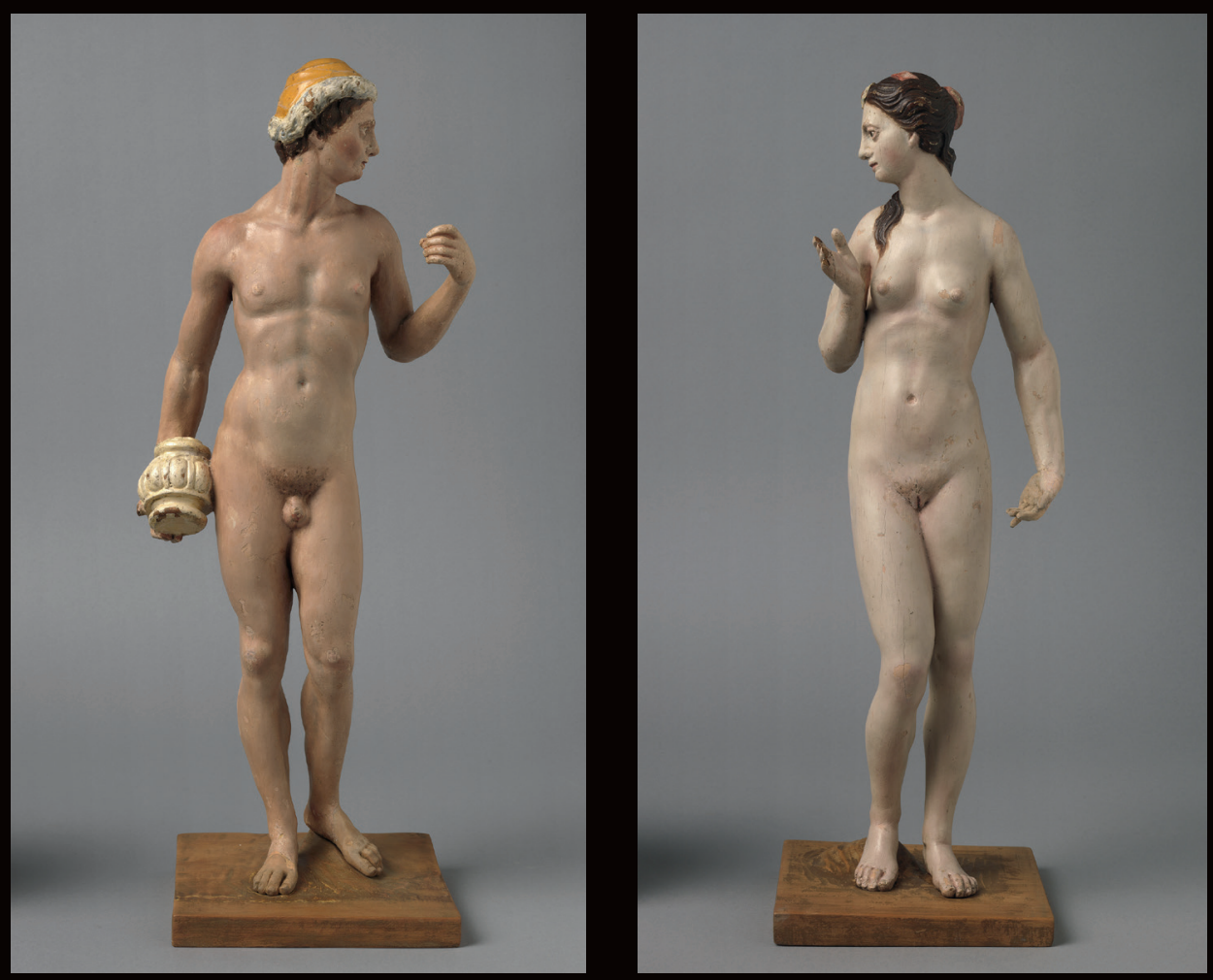

99. El Greco, Epimeteo y Pandora, hacia 1600-1610, Madrid, Museo Nacional del Prado 
en 1962 (il. 99). Desde hace décadas se viene asociando como fuente de esta pareja de tallas policromadas el célebre grabado a buril de Adán y Eva de Alberto Durero, fechado en $1504^{47}$; y últimamente, también se cree que la figura masculina deriva del David de Miguel Ángel y la femenina de la Venus de Médici - en posición invertida ${ }^{48}$. Las dos imágenes aparecen en perfecta responsión, dialogando antes de que se produzca la apertura de la caja en la que se contenían los males que habrían de asolar a la humanidad, tal como nos cuenta Hesíodo en Los trabajos y los días. Aunque lo habitual es que el recipiente aparezca en manos de Pandora, en esta versión es Epimeteo, el irreflexivo hermano de Prometeo, quien la sostiene. No conocemos la circunstancia de su encargo o si incluso pudo ser una creación para uso o disfrute del propio artista ${ }^{49}$.

\section{Hiszpańska rzeźba w czasach El Greca*}

\section{Streszczenie}

Zróżnicowany rozwój hiszpańskiej rzeźby w czasach El Greca (1541-1614) był następstwem pojawienia się włoskiego klasycyzmu wraz z modelami flamandzkimi i późniejszym wpływem Michała Anioła, trwającym aż do zwycięstwa barokowego naturalizmu na początku XVII wieku. Na tym tle analizujemy rzeźbę dworską, szczególnie świecką; ołtarz jako odzwierciedlenie religijnych programów ikonograficznych; wizerunki dewocyjne charakterystyczne dla duchowości Soboru Trydenckiego i rzeźbę procesyjną. Na koniec, na podstawie świadectw literackich i dokumentalnych przedstawiamy El Greca jako rzeźbiarza i analizujemy jego niewielką, lecz ciekawą spuściznę polichromowanych rzeźb drewnianych.

47 El Conde de las Infantas, ¿Dos esculturas de El Greco?, "Archivo Español de Arte" XVIII, 1945, p. 193-200; X. de Salas, Sobre dos esculturas del Greco, "Archivo Español de Arte" XXXIV, 1961, p. 297-301.

48 Y. Kitaura, El Greco. Génesis de su obra, Madrid 2003, p. 43-44.

49 L. Puppi, ¿Adán y Eva o Epimeteo y Pandora? Reflexiones sobre El Greco escultor, [en:] El Greco, ed. N. Sobregués, Barcelona 2003, p. 363-379.

* Przeł. Marta A. Urbańska. 